\title{
Syntheses of small cluster oligosaccharide mimetics
}

\author{
Andreas H. Franz,* Paul H. Gross, and Vyacheslav V. Samoshin \\ Department of Chemistry, University of the Pacific, Stockton, CA 95211, USA \\ E-mail: afranz@pacific.edu,vsamoshin@pacific.edu
}

Dedicated to Prof. Dr. Alan R. Katritzky on the occasion of his 80th birthday

\begin{abstract}
We designed multiple Small Cluster Oligosaccharide Mimetics (SCOMs) - potential glycosidase inhibitors - to be metabolically stable and small enough to enter cells or bacteria. Therefore, minimal scaffolds (urea, amide, ammonia) or simply non-glycosidic linkages of carbohydrate structures were central to our synthetic strategy, including: (a) coupling of several natural carbohydrate precursors; (b) total syntheses of aminomethyl tetrahydropyrans and their chiral amides with quinic acid; (c) glycopyranosyl cyanide reduction to prepare crowded clusters on a urea scaffold; (d) total syntheses via cycloadditions leading to amide-linked C-glycosides; (e) reduction of nitromethyl C-glycosides; and (f) a synthesis of hydroxylated 1,2cyclohexanedicarboxylic acids.
\end{abstract}

Keywords: Carbohydrate mimetics, aminomethyl $C$-glycosides, quinamides, glycals

\section{Table of Contents}

1. Introduction

2. Acylation with Quinic Lactone

3. Glycal Dimerization

4. Synthesis and Reduction of Glycosyl Cyanides

4.1. Glycosyl cyanides from glycosyl acetates

4.2. Glycosyl cyanides from glycals and glycal dimers

4.3. Reduction of glycosyl cyanides

5. Henry Condensation

6. Condensation with Malononitrile

7. Total syntheses of Aminomethyl-C-dideoxyglycopyranosides and their Quinamides

8. C-Glycosides via Cycloadditions

9. Hydroxy-derivatives of 1,2-cyclohexanedicarboxylic Acids 


\section{Introduction}

After the early years of carbohydrate chemistry around 1900 and Emil Fischer's structure proof of the carbohydrates, this area of chemistry received only little attention. However, carbohydrate chemistry witnessed a renaissance during the 1960's with the advent of the aminoglycoside antibiotics. ${ }^{1-3}$ Synthetic efforts since then have resulted in numerous structural modifications for carbohydrates. Exchange of aglycons on the anomeric carbon, exchange of the glycosidic atom $(\mathrm{N}-, \mathrm{C}-, \mathrm{S}$-glycosides), exchange of ring substitutents, exchange of the endocyclic heteroatom (carba-, aza-, thia-derivatives), and concise streochemical transformations. Oligosaccharides are now recognized to have functions influencing the entire spectrum of cell activities. Glycolipids and glycoproteins on the cell surface are now known to determine cell-cell interactions with invading bacteria, viruses, and cancer cells. $^{4-7}$ Carbohydrates play central roles in posttranslational modifications of proteins, ${ }^{8-10}$ cell-cell communication, ${ }^{11}$ and immune response to pathogens. ${ }^{10,12-14}$ Aberrations in glycosylation have been linked to severe pathological symptoms. Monosaccharide units combine to oligosaccharides in an almost infinite number of permutations, determined by the stereochemical identity of the linked monosaccharides (e.g. glucose, galactose, mannose), their glycosidic linkage position (e.g. $1 \rightarrow 4,1 \rightarrow 6$ ), their anomericity ( $\alpha$ or $\beta$ ), and the overall degree of branching. This complexity, further increased by additional modifications such as sulfation or sialation, was suggested recently to serve the evolutionary purpose of "herd immunity". ${ }^{15,16}$ It has become clear over the past three decades that glycosylation is critically important to many of the signaling pathways that turn a normal cell into a cancer cell. Compounds that inhibit specific glycosylation reactions may potentially block the pathways in carcinogenesis. Carbohydrates have been recognized as novel cancer prevention agents. ${ }^{17}$

However, a distinct disadvantage of naturally occurring carbohydrates, e. g. $O$-glycosidically-linked oligosaccharides, is their metabolic instability in biological systems. Therefore, much effort has been spent in the past two decades on the development of feasible pathways towards carbohydrate mimetics, including $C$-glycosidic sugars, ${ }^{18-21}$ which may compete with their $O$-glycosidic counterparts in cell surface adhesion, inhibit carbohydrateprocessing enzymes, and interfere in the biosynthesis of specific cell surface carbohydrates. ${ }^{21-23}$ Therefore, carbohydrate mimetics are potential therapeutic agents against HIV and other infections, against cancer, diabetes and other metabolic diseases. ${ }^{18-23}$

Oligosaccharide "clusters" exhibit greatly increased binding constants compared to monosaccharides (cluster effect). ${ }^{24-29}$ Potential targets for medical applications of these clusters have been identified. ${ }^{30}$ However, most synthesized glycosidic cluster compounds are too large to permeate cell walls or membranes, and only target cell surface receptors. ${ }^{24-29}$ Therefore, we devoted our work to the synthesis of a variety of Small Cluster Oligosaccharide Mimetics $(\mathrm{SCOMs})^{31,32}$ with enhanced metabolic stability, which presumably may enter the cytosol and internal cell substructures to address internal receptors. 


\section{Acylation with Quinic Lactone}

Quinic acid (1, Figure 1) ${ }^{33}$ and its derivative shikimic acid (2, Figure 1) ${ }^{34-36}$ (from Illicium japonica and floridanum) are key intermediates during the biochemical synthesis of essential aromatic amino acids, such as L-tryptophan, L-phenylalanine, and L-tyrosine in plants, bacteria, and fungi. Quinic acid and shikimic acid are also required as building blocks for the assimilation of folic acid, alkaloids, and vitamins in those organisms. ${ }^{37,38}$ The quinic acid/shikimic acid pathway does not exist in mammals, which has led to extensive research activities geared towards the development of suitable antibiotic therapeutics. Especially the conversion of 3dehydroquinic acid (DHQ) to 3-dehydroshikimic acid (DHS) has been recognized as an effective target for inhibition in plants. ${ }^{39,40}$ Several commercial herbicides selectively inhibit the DHQDHS conversion and prevent growth of weeds. However, disruption of the DHQ-DHS pathway by shikimic acid derivatives (3, Figure 1) has also recently been shown to cause therapeutic inhibition of Mycobacterium tuberculosis. ${ }^{41}$

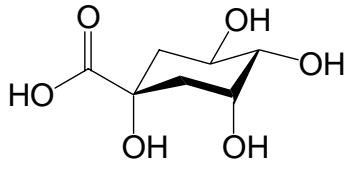

1

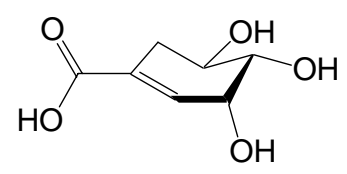

2
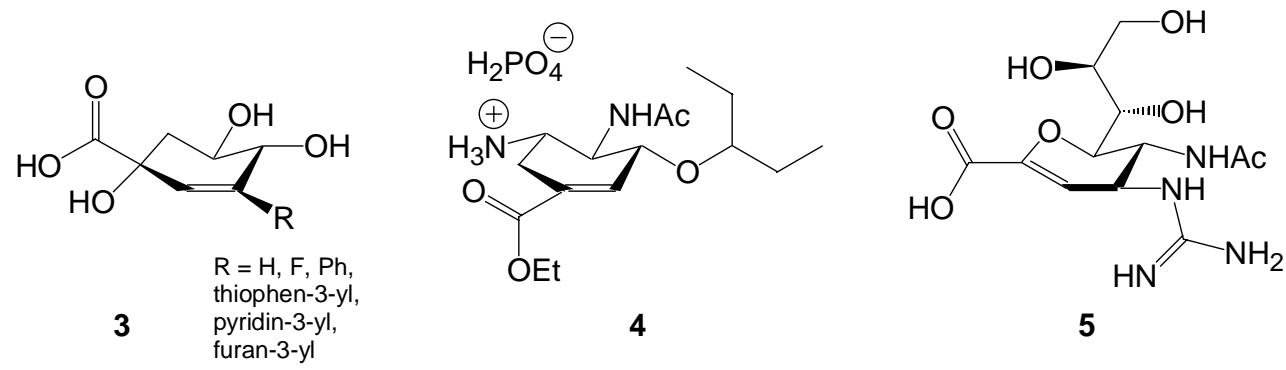

Figure 1. Chemical structures of quinic acid (1), shikimic acid (2). Compounds 3, 4 (Tamiflu ${ }^{\mathrm{TM}}$, Roche), and $\mathbf{5}$ (Relenza ${ }^{\mathrm{TM}}$, Glaxo-Smith) show anti-influenza activity.

Derivatives of shikimic acid have been used to inhibit other biochemical pathways for example the infectious pathway of the influenza virus (common flu). ${ }^{42-44}$ Potent anti-influenza $\mathrm{A}+\mathrm{B}$ effect has been observed for derivatives of shikimic acid inhibiting viral neuraminidase. The widely-prescribed anti-flu medication Tamiflu ${ }^{\mathrm{TM}}$ (Roche, 4, Figure 1) is not only effective in treating common flu strains, but it has also been used successfully in the treatment of the bird (avian) flu in laboratory animals. Contrary to animal experiments, Tamiflu's ${ }^{\mathrm{TM}}$ effectiveness in humans infected with the H5N1 flu strain is still controversial because only a few studies with limited statistical value have been conducted, and the understanding of the drug's action against the virus is only rudimentary. Tamiflu ${ }^{\mathrm{TM}}$ acts as influenza virus neuraminidase inhibitor with the possibility of alteration of virus particle aggregation and release. The less well-known Relenza ${ }^{\mathrm{TM}}$ 
(Zanamivir, GlaxoSmithKline, 5, Figure 1) ${ }^{42}$ is also an effective inhibitor of common flu strains by the same mechanism. The problem of a sufficient supply of these two drugs in case of an influenza pandemic and the necessity for a continuous search for new structural analogs has been discussed in the literature. ${ }^{45,46}$

For the construction of SCOMs from quinic acid, we used 2-amino-2-deoxy sugars as nucleophiles and quinic lactone as an electrophile (Scheme 1). ${ }^{47-49}$ Starting with 2-acetamido-2deoxy-D-glucopyranose (6), we prepared the corresponding benzyl glucoside (7) through acidcatalyzed acetal formation. Under these conditions, compound 7 was obtained as a mixture of anomers, which was difficult to separate or crystallize. However, the $\alpha$ - and $\beta$-anomer can be obtained clean after per-O-acetylation, recrystallization, and $\mathrm{MeO}^{-} / \mathrm{MeOH}$ deprotection at room temperature. $^{50}$ Compound 7 was then converted to the 4,6-O-benzylidene derivative 8 with benzaldehyde and anhydrous $\mathrm{ZnCl}_{2}$ followed by removal of the $\mathrm{N}$-acetyl group in ethanolic $\mathrm{KOH}$ at reflux to yield 2-amino-4,6-O-benzylidene-2-deoxy- $\alpha / \beta$-D-glucopyranose (9). In parallel, D-(-)-quininc acid was converted to the 4,5-O-isopropylidenated lactone (11) ${ }^{51}$ which served as an electrophile in the subsequent acylation of the separated $\alpha$ - and $\beta$-anomers $\mathbf{9 a} / \mathbf{b}$ into the potential disaccharide mimic precursors $12 \mathbf{a} / \mathbf{b}$, respectively.

We also prepared compounds 21 and 22 as regio- and diastereochemical analogs of $\mathbf{1 2}$, respectively. The two corresponding aminoglycosides were synthesized from D-glucose (14). ${ }^{52}$ Benzylation followed by 4,6-O-benzylidenation gave compound 16 whose 2- and 3-hydroxyl groups were subsequently mesylated to afford compound 17. Upon treatment of 17 with methoxide, we were able to obtain benzyl-2,3-anhydro-4,6-O-benzylidene- $\alpha$-D-allopyranoside (18). The epoxide was surprisingly stable but could be opened with $\mathrm{NH}_{3}$ under pressure and elevated temperature. The major product (20) with D-altro-configuration was obtained through diaxial opening (Fuerst-Plattner rule) whereas the regioisomer (19) with D-gluco-configuration was only isolated in small quantities from the same reaction. When these products were combined with quinic lactone 11, SCOMs 21 and 22 were obtained, respectively.

Interestingly, the quinic amide ring in all quinamides described above had a predominant twist-boat conformation as determined by NMR in $\mathrm{CDCl}_{3}$ (Scheme 1). ${ }^{47,48}$ This was confirmed by small gauche ${ }^{3} \boldsymbol{J}$-values and NOEs between $\mathrm{H} 3 / \mathrm{H} 2 \mathrm{a} / \mathrm{H} 2 \mathrm{~b}$ and between $\mathrm{H} 5 / \mathrm{H} 6 \mathrm{a} / \mathrm{H} 6 \mathrm{~b}$, as well as a significant ${ }^{4} \boldsymbol{J}$ between $\mathrm{H} 4$ and $\mathrm{H} 2 \mathrm{~b}$ (W-coupling). We observed the same conformation for the unsubstituted quinamide 13 that was obtained from 11 in a saturated methanolic solution of $\mathrm{NH}_{3}$ at room temperature. This benzylamide derivative had been described by us earlier; however, without detailed conformational analysis (Scheme 1). ${ }^{49}$ The twist-boat conformation is pretty common for the pyranoses/tetrahydropyranes fused to five-membered acetal ring(s) (e.g. see Section 4.1), but is very rare for cyclohexane derivatives.

Quinic lactone $\mathbf{1 1}$ was also used for acylation of synthesized aminomethyl-Cdideoxyglycopyranosides (Section 7). 

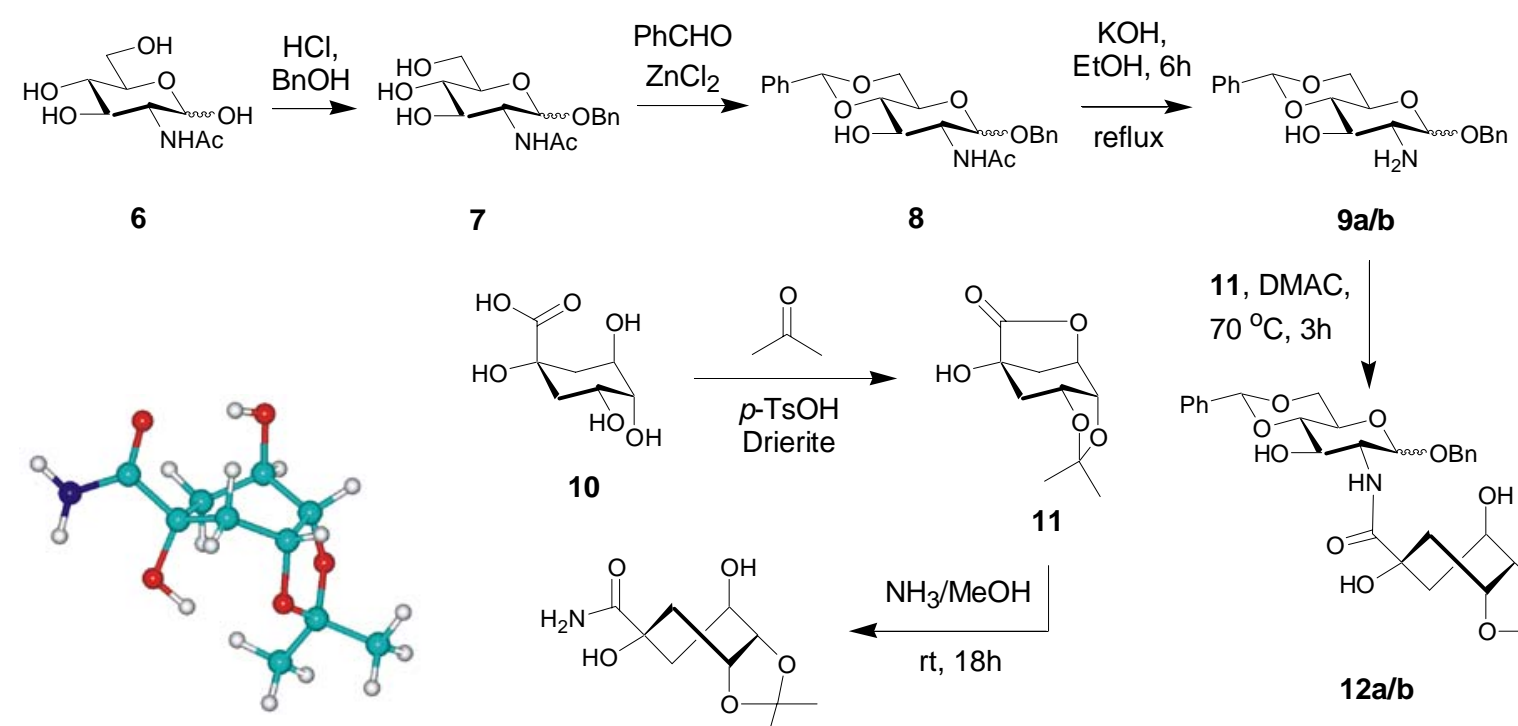

7

8
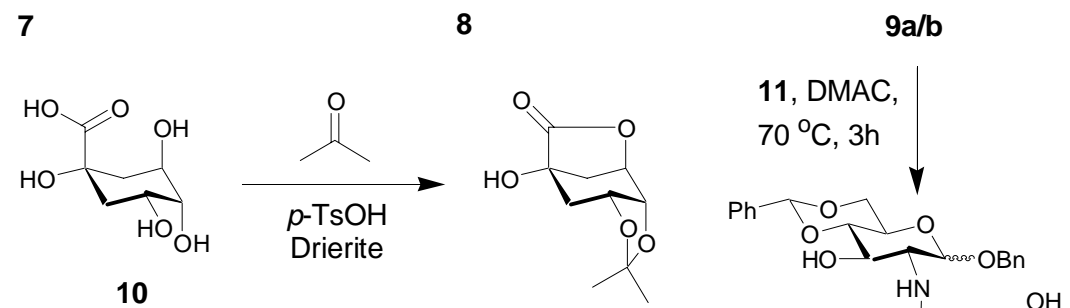

11
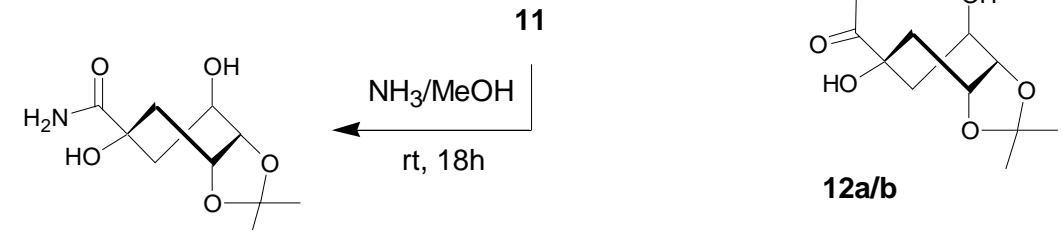

13
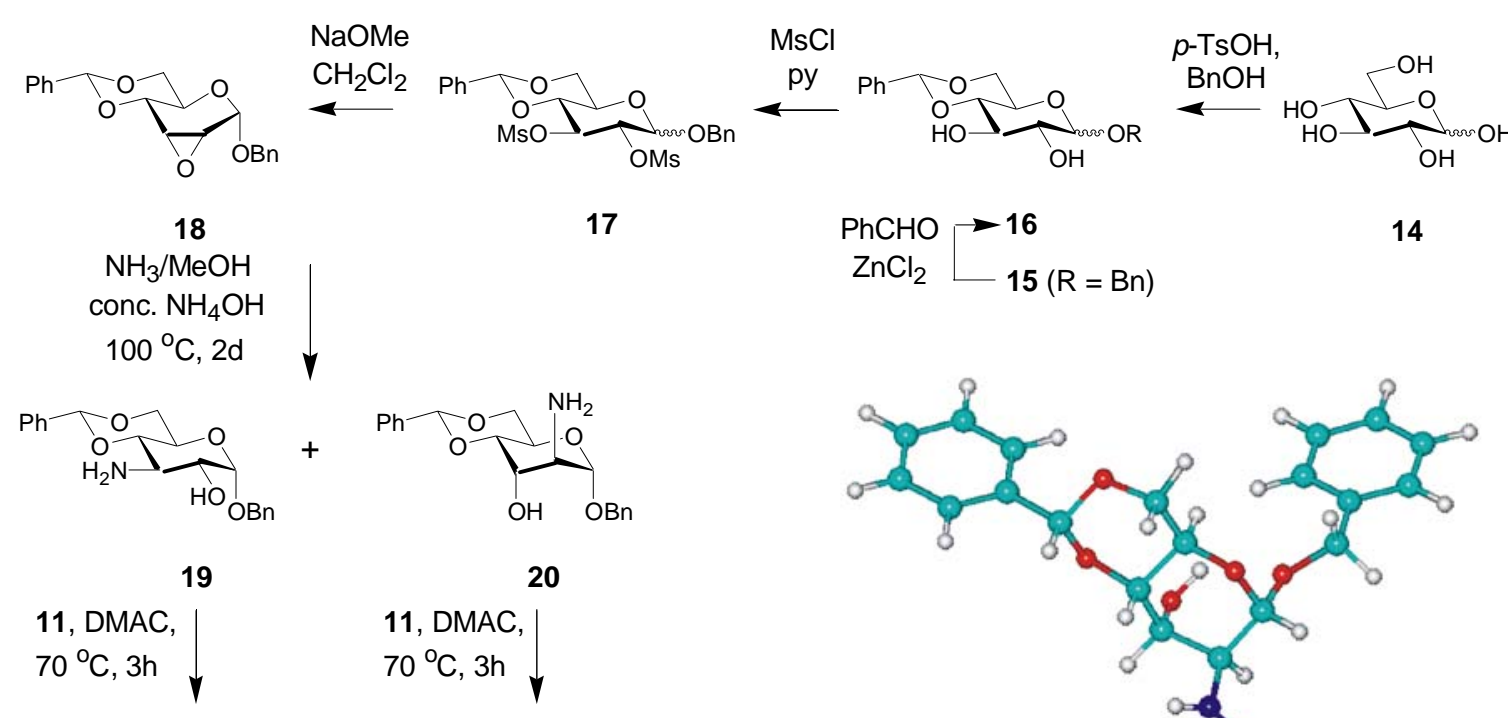

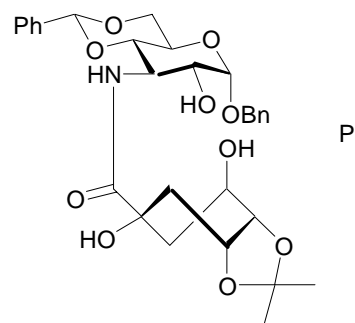

21
17

$\mathrm{PhCHO}$
$\mathrm{ZnCl}_{2}$

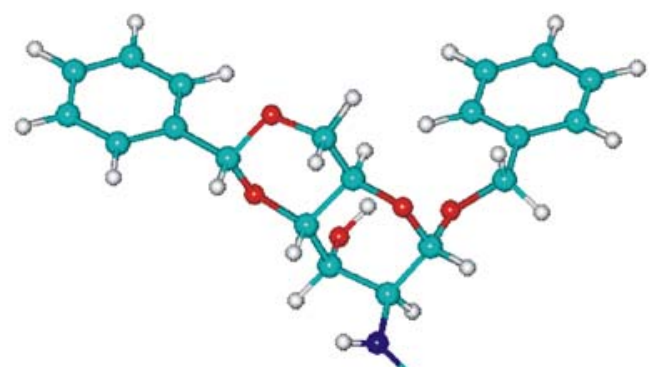

Scheme 1. Quinamide SCOMs synthesized through nucleophilic opening of quinic lactone. ${ }^{47-49}$ The molecular models represent $0 \mathrm{~K}$ structures obtained from molecular dynamics simulation (AM1) with temperature annealing. 


\section{Glycal Dimerization}

Glycals (1,2-eno-pyranoses or -furanoses) are versatile chiral building blocks in the synthesis of natural products and biologically relevant oligosaccharides, ${ }^{53}$ because of the ease of their chemical transformation. ${ }^{54-57}$ Synthetic oligosaccharides derived from glycals have been tested as antigens in anti-cancer vaccination. ${ }^{53,58}$

Glycals are classically synthesized by reduction (1,2-deacetoxybromination) of per-O-acetylated glycosyl bromides in glacial $\mathrm{AcOH} / \mathrm{NaOAc}$ buffer with $\mathrm{Zn} .{ }^{59,60}$ However, these literature procedures have serious problems, ${ }^{59-61}$ among which solvolysis of the unstable intermediate glycosyl bromides is the major one.

We have developed a synthesis of acetylated glycosyl bromides and subsequently glycals from per-acetylated sugars under non-solvolytic conditions. ${ }^{62-64} \mathrm{In}$ the first step a per-Oacetylated sugar was treated with $\mathrm{TiBr}_{4}$ in $\mathrm{CH}_{2} \mathrm{Cl}_{2}$ in presence of a catalytic amount of glacial acetic acid. The resulting glycosyl bromide was in situ reduced with $\mathrm{Zn} / \mathrm{Cu}$ couple. Per-Oacetylated D-glucose, D-galactose, D-glucuronic acid methyl ester, L-fucose, D-maltose, D-lactose, and D-gentiobiose gave corresponding glycals 23-30 (Figure 2) in $>90 \%$ purity prior to purification, as estimated by NMR. ${ }^{62-64}$

$$
\mathrm{R}=\mathrm{OAC}
$$

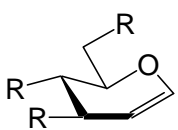

23, from

D-glucose (81\%)

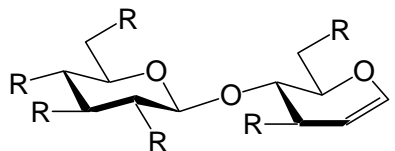

27, from

D-cellobiose

(75\%)

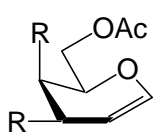

24, from

D-galactose (65\%)

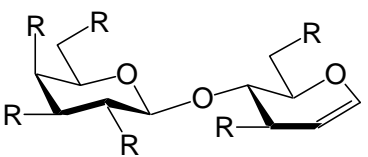

28, from

D-lactose

(78\%)

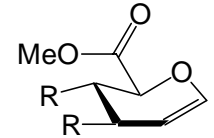

25 , from

D-glucuronic acid

(75\%)

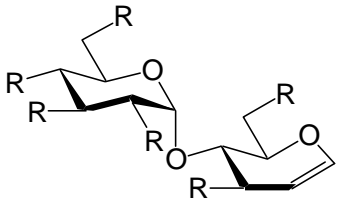

29, from

D-maltose

(73\%)

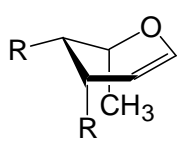

26, from

L-fucose

(70\%)

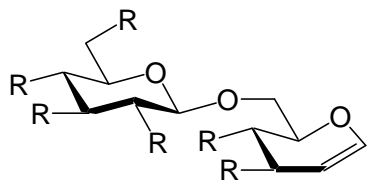

30, from

D-gentiobiose (95\%)

Figure 2. Glycals synthesized under aprotic conditions. ${ }^{62-64}$

Dimerization of per-O-acetylated D-glucal was described first by Ferrier and Prasad. ${ }^{65}$ In a

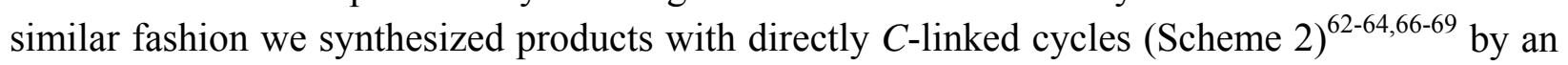
improved dimerization method with $\mathrm{BF}_{3} / \mathrm{Ac}_{2} \mathrm{O}$ catalyst, ${ }^{67}$ and also obtained tetrasaccharidic glycomimetics from disaccharidic glycals (Scheme 3). ${ }^{62-64,66-69}$ 


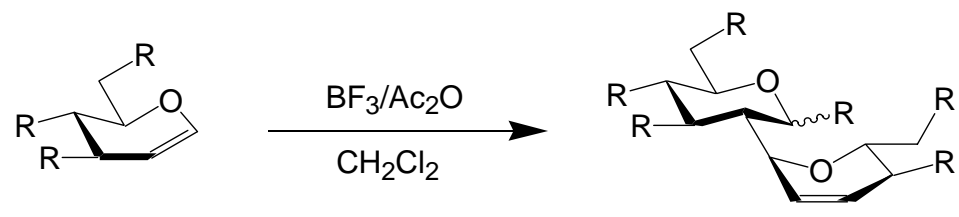

23

$31(55 \%)$

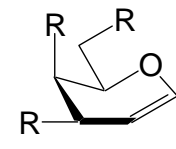<smiles>CC(Br)CCC(=O)C(Br)Br</smiles>

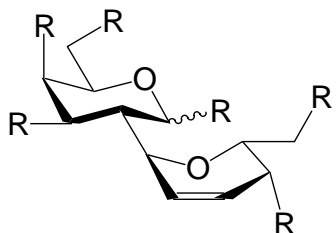

24

$32(44 \%)$<smiles>[R]C1C2CC(C2)OC(C)C1[R]</smiles>

26

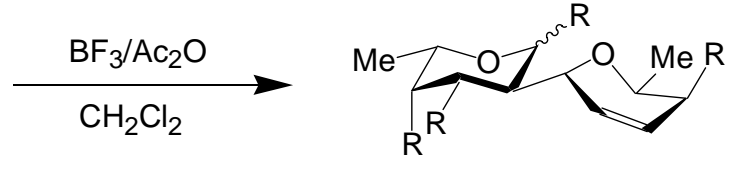

$33(60 \%)$

$$
\mathrm{R}=\mathrm{OAc}
$$

Scheme 2. Structures of products from glycal dimerization. ${ }^{62-64,66-69}$

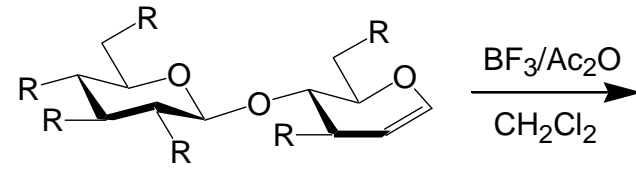

27

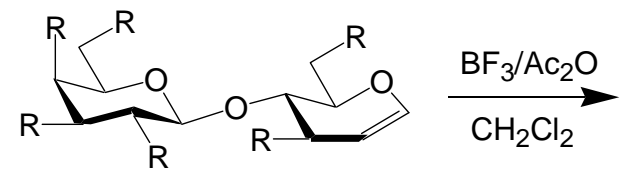

28

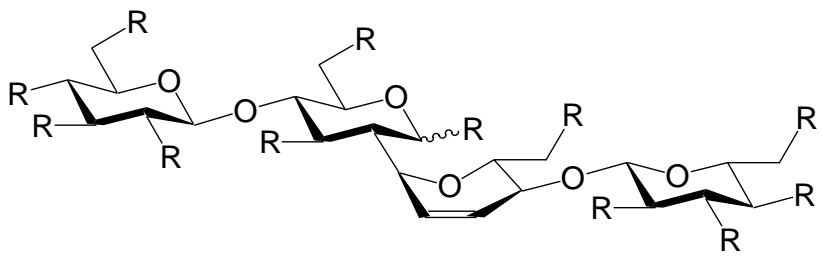

$34(20 \%)$

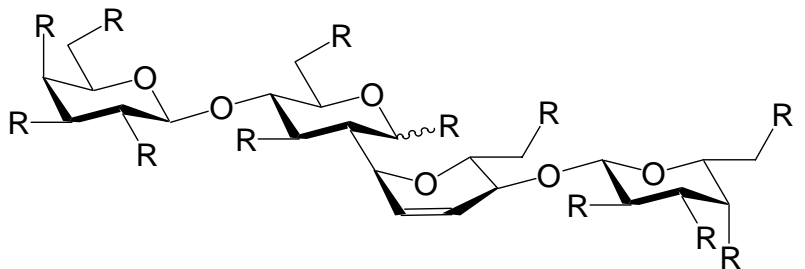

$35(10 \%)$

$$
\mathrm{R}=\mathrm{OAC}
$$

Scheme 3. Dimerization of per-O-acetyl-cellobial 27 and per-O-acetyl-lactal $28{ }^{62-64,66-69}$

Such compounds may potentially show altered and/or enhanced bioactivity due to a welldocumented cluster effect. $^{24-29}$ The non-physiological nature of the new C-C-linkages in our compounds may transfer metabolic stability also to $O$-glycosidic bonds still present in their 
structures. Dimerizations of disaccharidic glycals to tetramers required careful optimization of conditions to minimize cleavage of the disaccharidic bonds by the $\mathrm{BF}_{3}$-catalyst.

The structural assignment of glycal dimers was based upon NMR data. The original assignment for tri-O-acetyl-D-glucal dimer $31^{65}$ was confirmed by our data, ${ }^{64,66}$ and finally proved by X-ray crystal structure analysis (Figure 3 ). ${ }^{66}$

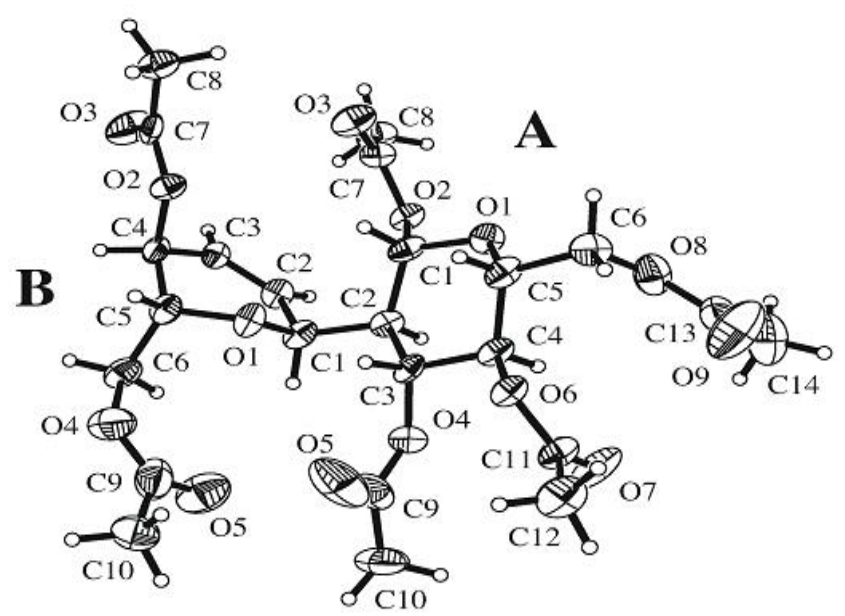

Figure 3. Molecular structure of compound $31{ }^{66}$

The structural analysis of $\mathbf{3 1}$ revealed a high degree of rigidity in the molecule. Comparative analysis of the NMR and X-ray data ${ }^{62,64,66}$ shows that there is virtually no difference between the solution and crystal conformations of both rings in compound 31. The average position of the two ring planes in $\mathbf{3 1}$ may be considered nearly perpendicular. The conformational equilibrium for both rings appears to be strongly biased. An absence of a solvent dependence for spin-spin coupling constants also supports these conclusions.

The results of this work combined with literature data allowed us to suggest a set of "standard" coupling constants for use in structural analysis of 2,3-dideoxy-2-enopyranose systems with $\alpha$-erythro configuration in the unusual ${ }^{5} \mathrm{H}_{\mathrm{O}}$-conformation and more common ${ }^{0} \mathrm{H}_{5^{-}}$ conformation (Figure 4). ${ }^{62,64,66}$

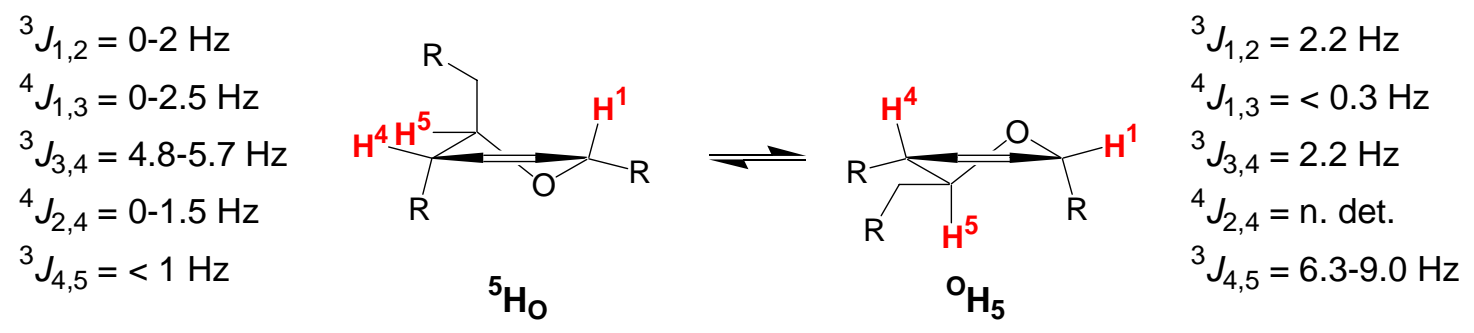

Figure 4. Refined "standard" coupling constants for ${ }^{5} \mathrm{H}_{\mathrm{O}^{-}}$and ${ }^{0} \mathrm{H}_{5}$-conformations of 2,3dideoxy-2-enopyranose system..$^{62,64,66}$ 


\section{Synthesis and Reduction of Glycosyl Cyanides \\ 4.1. Glycosyl cyanides from glycosyl acetates}

Another way to render carbohydrate-derived structures metabolically more stable is offered by introducing a $C$-glycosidic cyanide functionality. In 1961 Helferich and Bettin obtained per-Oacetyl- $\beta$-D-galactopyranosyl cyanide in good yield from per-O-acetyl- $\alpha$-D-galactopyranosyl bromide and mercuric cyanide in nitromethane ${ }^{70}$ However, the analogous reaction of per-Oacetyl- $\alpha$-D-glucopyranosyl bromide ${ }^{71-74}$ gave per-O-acetyl-1,2-O-(1-cyanoethylidene)- $\alpha$-Dglucopyranose 36 in $53 \%$ yield, and only $11 \%$ of the preferred per- $O$-acetyl- $\beta$-D-glucopyranosyl cyanide 37. The preparation of per-O-acetyl-glycopyranosyl cyanides by Myers and Lee brought little improvement. ${ }^{75,76}$

Better overall yields of glycosyl cyanides could be obtained by exchange of the anomeric $\mathrm{O}$-acyl group with the cyanide of trimethylsilyl cyanide (TMS-CN) in the presence of $\mathrm{BF}_{3}-\mathrm{OEt}_{2}$ in nitromethane. ${ }^{77-80}$ Thus, per- $O$-acetyl- $\alpha / \beta$-D-galactopyranoses could be directly converted into per-O-acetyl- $\beta$-D-galactopyranosyl cyanide. $\mathrm{But} \mathrm{BF}_{3}-\mathrm{OEt}_{2}$ is hazardous, unstable, and harsh, and significant decomposition and incompatibility with glycosidic bonds were observed. However, the elimination of the unstable glycosyl bromides as intermediates was a distinct advantage. We decided to investigate the use of $\mathrm{HgBr}_{2}$, as a milder catalyst for this reaction (Schemes 4,5). ${ }^{81-83}$

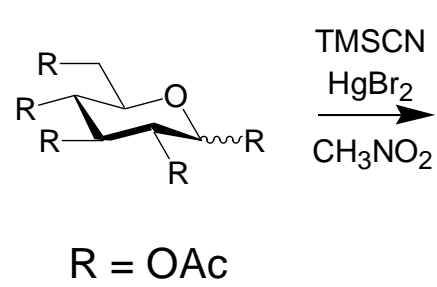

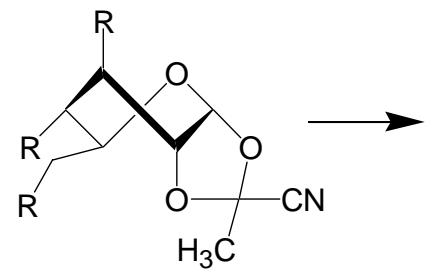

36

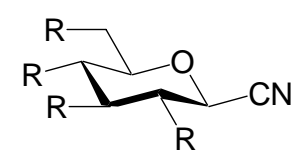

37

Scheme 4. Synthesis of per-O-acetyl- $\beta$-D-glucopyranosyl cyanide $37 .{ }^{81-83}$

When per-O-acetyl- $\alpha$ - or $\beta$-D-glucopyranose was treated with excess TMS-CN and 0.1 molar equiv of $\mathrm{HgBr}_{2}$ in nitromethane for 2 days in the absence of $\mathrm{Hg}(\mathrm{CN})_{2}$, the major product was the 1,2-cyanoethylidene derivative 36 in $59 \%$ yield, along with only $5 \%$ of the preferred cyanide 37 , and about $28 \%$ of starting material (Scheme 4 ), ${ }^{81-83}$ similar to the results of Coxon and Fletcher with $\mathrm{Hg}(\mathrm{CN})_{2} \cdot{ }^{71}$ When we increased the amount of $\mathrm{HgBr}_{2}$ to at least 0.5 equiv, the cyanoethylidene intermediate rearranged into the desired per-O-acetyl- $\beta$-Dglucopyranosyl cyanide 37 in $51 \%$ yield starting from per- $O$-acetyl- $\beta$-D-glucopyranose, or $65 \%$ yield from purified cyanoethylidene intermediate 36, within 1 day. Yields of rearrangement decreased to $5 \%$ when no TMS-CN was added along with the catalyst, and complete decomposition occurred on warming. The omission of $\mathrm{Hg}(\mathrm{CN})_{2}$ was crucial. This suggested that rearrangement required the assistance of a mercuric isocyanide complex in conjunction with the 
existence of equilibrium between the exo-cyanoethylidene 36 and the acetoxonium intermediate. $^{82,83}$

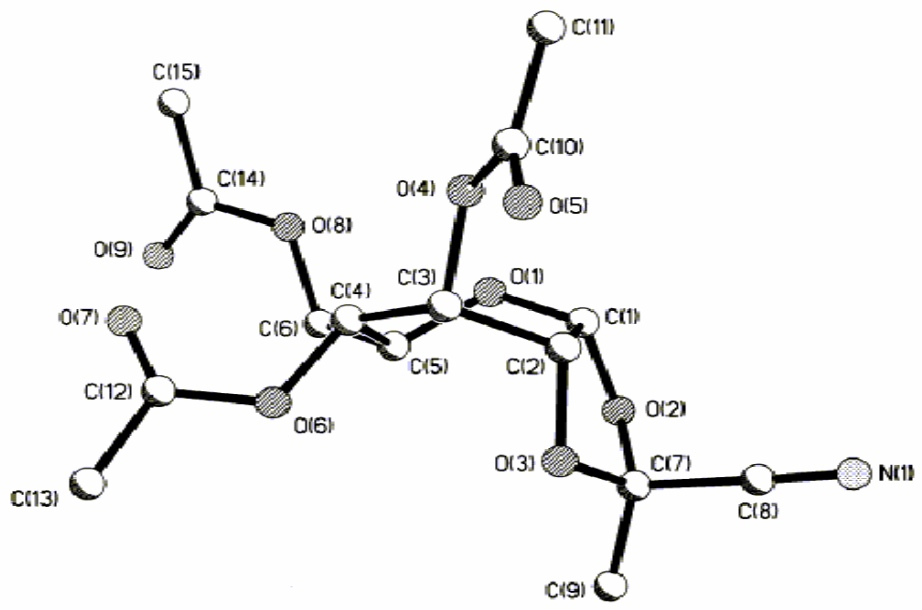

Figure 5. Molecular structure of the only isolated intermediate: per-O-acetyl-2-O-(1-exoethylidene)- $\alpha$-D-glucopyranose $36 .{ }^{84}$

Cano et. al. $^{85}$ have already done extensive studies on the conformations of per-O-acetyl-1,2$O$-(1-cyanoethylidene)- $\alpha$-D-glycopyranoses, which were obtained from the reactions of glycosyl bromides with potassium cyanide in tetrabutylammonium bromide/acetonitrile. ${ }^{86} \mathrm{X}$-Ray crystallographic $^{84}$ and NMR analyses of the enantiomerically pure cyanoethylidene intermediate 36 from our procedure showed it to exist in a twist-boat conformation of the six-membered cycle, with the cyanide exclusively in the exo-position (Figure 5).

With excess TMS-CN and 0.1 molar equivalents of $\mathrm{HgBr}_{2}$ in nitromethane, per-O-acetyl$\alpha($ or $\beta$ )-L-fucopyranose was converted into per- $O$-acetyl- $\beta$-L-fucopyranosyl cyanide 39 in $95 \%$ yield within $4 \mathrm{~h}$. We observed neither the cyanoethylidene compound $\mathbf{3 8}$ as an intermediate ${ }^{86}$ nor decomposition, but only a trace of the $\alpha$-anomer of 39 (Scheme 5). ${ }^{81-83}$

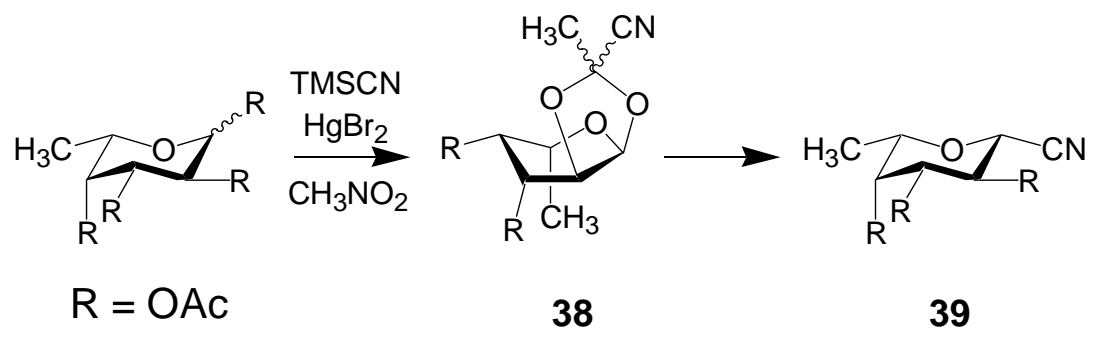

Scheme 5. Synthesis of per-O-acetyl- $\beta$-L-fucopyranosyl cyanide $39 .^{81-83}$

The 1,2-O-(cyanoethylidene) glycopyranose side products were obtained by Myers and Lee in a larger yield from per-O-acetyl-D-gluco- and mannopyranose than from per-O-acetyl- 
D-galactose. ${ }^{75,76}$ They tried to rearrange these syrupy byproducts into the corresponding $\alpha / \beta$ cyanides with boron trifluoride-etherate $\left(\mathrm{BF}_{3}-\mathrm{OEt}_{2}\right)$ but improved the glycosyl cyanide yield only slightly. Kini et al. found it necessary to elevate the reaction temperature to $35^{\circ} \mathrm{C}$ to minimize formation of the 1,2-O-(cyanoethylidene) mannopyranoses when a mixture of per-Oacetyl- $\alpha / \beta$-mannopyranoses was converted with $\mathrm{TMS}-\mathrm{CN} / \mathrm{BF}_{3}-\mathrm{OEt}_{2}$ into $\alpha$-D-mannopyranosyl cyanide. $^{87}$

\subsection{Glycosyl cyanides from glycals and glycal dimers}

DeLas Heras et al. have shown that glycals, as well as glycosyl acetates, can be transformed with $\mathrm{BF}_{3}-\mathrm{Me}_{3} \mathrm{SiCN}$ in nitromethane into 2,3-unsaturated glycosyl cyanides, or glycosyl cyanides, respectively. ${ }^{79}$ The complex stereospecificity, if any, of such $\mathrm{S}_{\mathrm{N}}$ '-reactions has been discussed by March. ${ }^{88}$ More recently, alternative methods for the preparation of 2,3-unsaturated glycosyl cyanides from protected or unprotected glycals have been developed. ${ }^{89,90}$ We used a milder reagent for the introduction of a cyanide functionality, $\mathrm{Hg}(\mathrm{CN})_{2} / \mathrm{HgBr}_{2} / \mathrm{Me}_{3} \mathrm{SiCN}$ in THF/MeCN (2:3), to transform tri- $O$-acetyl-D-glucal 23 into 2,3-unsaturated di-O-acetyl-D-glucosyl cyanide 40 (Scheme 6). ${ }^{62-64,91,92}$

We could use this reagent not only to convert $O$-glycosidic glycals into 2,3-eno-pyranosyl cyanides (Scheme 6) but also to obtain anomeric cyanides from glycal dimers and tetramers (Scheme 7) which are 2-C-2-deoxy-sugars. ${ }^{62-64,92}$ The reagent was compatible with 1,4- and 1,6$O$-glycosidic linkages, which are normally prone to cleavage in the presence of $\mathrm{BF}_{3}{ }^{79}$

The reagent $\mathrm{Hg}(\mathrm{CN})_{2}, \mathrm{HgBr}_{2}$ and TMSCN, applied to compound 31, replaced the anomeric acetate group in ring $\mathrm{A}$, to give the expected glycosyl cyanide 45 (Scheme 7). ${ }^{62-64}$ However, compound 33 (a dimer from tri-O-acetyl-L-fucal) gave unexpectedly the doubly unsaturated cyanide 47 (Scheme 7). ${ }^{62-64,92}$ Similarly, the galactal dimer 32 gave a doubly unsaturated cyanide 46. Although the dimers 32 and $\mathbf{3 3}$ had only a stereochemical difference with $\mathbf{3 1}$ in the relative disposition of the 4-acetoxy group, the substitution of the anomeric acetoxy group was attended by elimination of $\mathrm{AcOH}$, with deprotonation at $\mathrm{C}-2{ }^{62-64,92} \mathrm{~A}$ relief of steric strain may be a driving force for this elimination. Indeed, the molecular mechanics calculations (MM+) revealed a substantially higher steric strain (by $3-4 \mathrm{kcal} / \mathrm{mol}$ ) in the most stable conformation of 33 when compared with 6A,6B-dideoxy analog of 31, which is a stereoisomer of 33 . The remote C-4 ${ }^{\mathrm{A}}$ acetoxy group, which functions as an internal base, may facilitate the deprotonation of an intermediate oxonium ion by intramolecularly removing and transporting the proton ultimately to external $\mathrm{CN}^{-}$, like a miniature crane. Such a "crane effect" does not work in 31, which has a different orientation of the $\mathrm{C}-4^{\mathrm{A}}$ acetoxy group. ${ }^{62-64,92}$ 


$$
\mathrm{R}=\mathrm{OAC}
$$

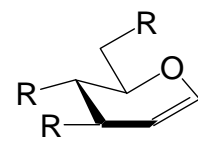

23
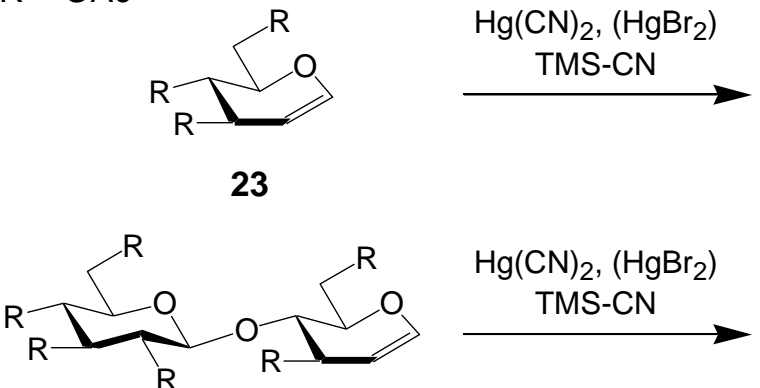

27

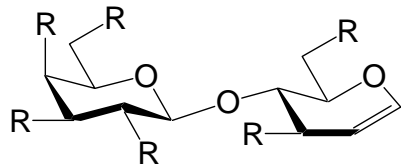

28

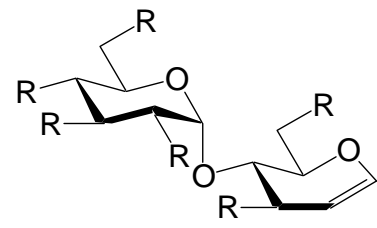

29

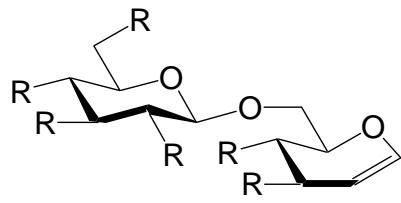

30

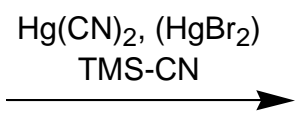

$\mathrm{Hg}(\mathrm{CN})_{2},\left(\mathrm{HgBr}_{2}\right)$ TMS-CN
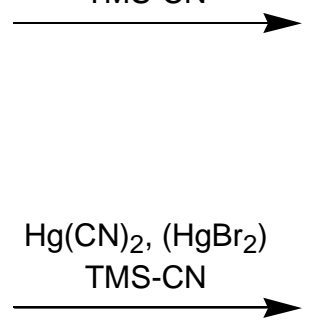

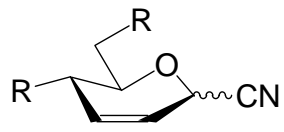

40

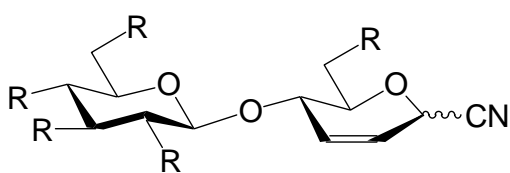

41

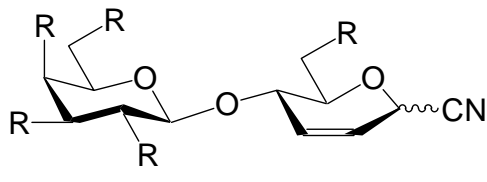

42

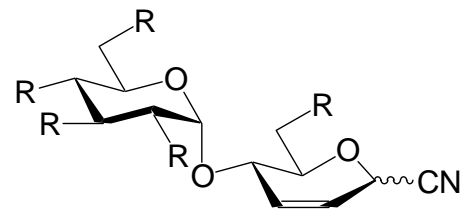

43

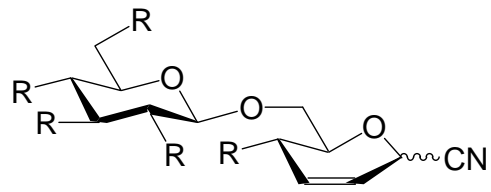

44

Scheme 6. Cyanation of per-O-acetyl-glucal and disaccharidic per-O-acetyl-glycals. ${ }^{62-64,91,92}$ 


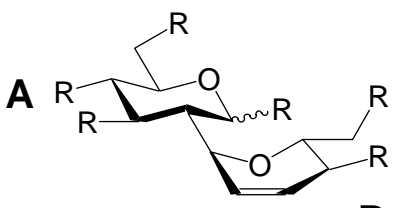

31

$\mathrm{R}=\mathrm{OAC}$

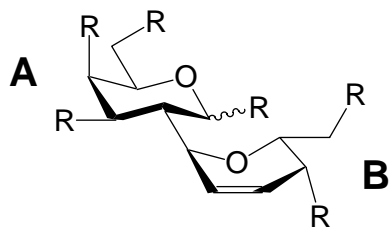

32

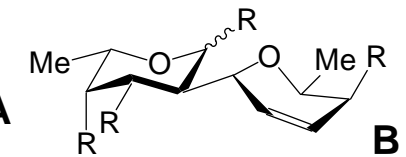

33

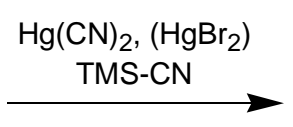

$\mathrm{Hg}(\mathrm{CN})_{2},\left(\mathrm{HgBr}_{2}\right)$ TMS-CN

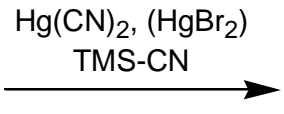

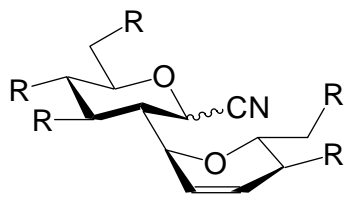

$45(93 \%, \alpha / \beta$ 1:2)

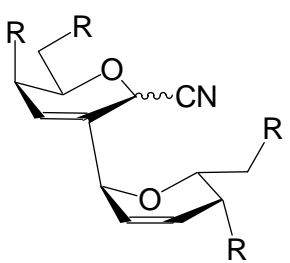

$46(81 \%, \alpha / \beta$ 10:1)

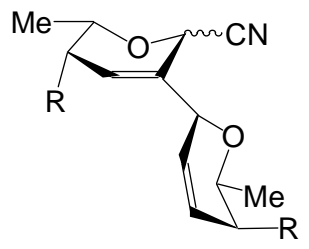

$47(34 \%, \alpha / \beta$ 10:1)

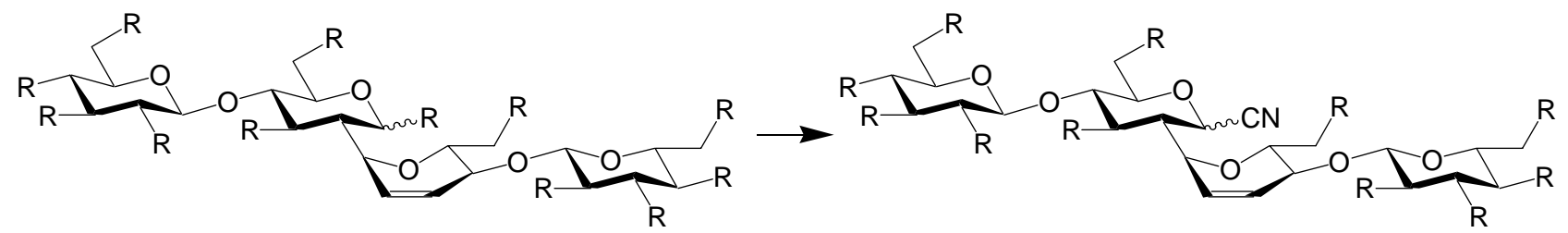

34

$48(52 \%, \alpha / \beta 10: 1)$

Scheme 7. Cyanation products from glycal dimers. ${ }^{62-64,92}$

\subsection{Reduction of glycosyl cyanides}

One versatile approach to glycosyl cyanide modification, with which we have considerable experience, is catalytic reduction. ${ }^{81,82,93-96}$ Hydrogenation of per- $O$-acetyl- $\beta$-L-fucopyranosyl cyanide 39 with catalytic palladium-charcoal in the presence of acetic anhydride $\left(\mathrm{Ac}_{2} \mathrm{O}\right)$ gave the isolated $\mathrm{O}-\mathrm{N}$-acetyl migrated products 49 and 50 in $32 \%$ and $23 \%$ yields, respectively (Scheme 8). ${ }^{81,82,94-96}$ The yield for the $N$-linked aminodisaccharide 50 decreased to $9 \%$ without the presence of $\mathrm{Ac}_{2} \mathrm{O}$. Since the presence of $\mathrm{Ac}_{2} \mathrm{O}$ did not prevent migration, it appeared that $\mathrm{O}-\mathrm{N}$-acetyl migration from a 2-O-acetoxyl group was much faster than acetylation of the amines. The 2-hydroxyl amino- $C$-monosaccharide 49 and $C$-disaccharide 50 can be acetylated with $\mathrm{Ac}_{2} \mathrm{O}$ in the presence of catalytic 1,4-(dimethylamino)pyridine (DMAP) to the corresponding fully protected $\mathbf{5 1}$ and $\mathbf{5 2}$ before or after isolation. . $1,82,94-96^{-9}$ 
In the presence of the lipophilic $\mathrm{Boc}_{2} \mathrm{O}$, the hydrogenation of cyanide 39 on $\mathrm{Pd} / \mathrm{C}$ gave only 53 and an $N$-linked disaccharide 54 in $61 \%$ and 38\% yields, respectively, without $O$ - $N$-acetyl migrations (Scheme 8). ${ }^{81,82,94-96}$ Again, the yield of disaccharide 54 was increased in presence of the anhydride.

Cyanides are reduced with $\mathrm{H}_{2} / \mathrm{Pd}$ in two stages. ${ }^{97}$ The first stage is formation of aldimine, and the second is reduction to the corresponding amine. In the production of 49 and 50, O-Nacetyl migration could occur at the aldimine or amine stage. The migration at the stage of amine made it unavailable for further reaction. That no acetyl migratory product was observed in the presence of $\mathrm{Boc}_{2} \mathrm{O}$ suggests fast reaction of aldimines and amines with $\mathrm{Boc}_{2} \mathrm{O}$ at the lipophilic charcoal catalyst surface. In contrast, hydrophilic $\mathrm{Ac}_{2} \mathrm{O}$, present in the bulk solution, permits acetyl migrations at the surface. The more electrophilic acylated aldimines tend to favor dimerization, which indeed occurred more readily in the presence of $\mathrm{Ac}_{2} \mathrm{O}$ and $\mathrm{Boc}_{2} \mathrm{O} .^{81,82,94,95}$ This point was not appreciated by Lentz et al. in their later work with $\mathrm{Boc}_{2} \mathrm{O},{ }^{98}$ probably because they did not compare hydrogenation in the presence of $\mathrm{Ac}_{2} \mathrm{O}$, as we did.

From the Boc-protected aminomethyl-C-fucopyranoside synthons, a great variety of biologically interesting glycoconjugates are accessible. Transformation of the $1^{\circ}$ amino functionality into an isocyanate allows coupling with the former $1^{\circ}$ amine or the $2^{\circ}$ amine dimer. Other nucleophiles would give glycoconjugates with minimal scaffolding such as unsymmetrical ureas. This could be accomplished in many ways, but most commonly by phosgenation, ${ }^{99}$ which is economical and practical, since the advent of crystalline "triphosgene". We removed the Boc-protective group from the aminomethyl- $\mathrm{C}$-monosaccharide 53 with TosOH- $\mathrm{H}_{2} \mathrm{O}$ in $\mathrm{CH}_{2} \mathrm{Cl}_{2}$, and the resultant salt, in solution, was directly converted with $1 / 6$ equivalents of triphosgene in a $\mathrm{CH}_{2} \mathrm{Cl}_{2}$-saturated sodium bicarbonate two-phase system (Scheme 8), via the in situ amino- and isocyanato-monosaccharide intermediates, into the novel di-fucopyranosyl methyl-substituted urea 55 in 63\% yield, along with $49(12 \%)$ through $\mathrm{O}-\mathrm{N}$-acetyl migration. ${ }^{81,82,94-96}$

When the same deprotection and two-phase phosgenation was applied to the $N$-linked disaccharide 54, a novel tetra-fucopyranosyl methyl-substituted urea 57 (28\%) was obtained along with the $\mathrm{O}-\mathrm{N}$-acetyl migratory side-product $50(48 \%)$ and the stable crystalline carbamoyl chloride 56 (15\%; Scheme 8) - a potentially useful reactant for preparation of more complex $C$ glycosidic conjugates. The yield for the tetra-substituted urea derivative was surprisingly high for a bimolecular reaction of two sterically hindered intermediates, which had to compete with the major intramolecular pathway of acetyl migration, after Boc removal. Formation of acetyl migratory side products $\mathbf{4 9}$ and $\mathbf{5 0}$ was increased if a weaker acid such as trifluoroacetic acid was employed to remove the Boc-protective group, or if Hünig's base was used in a single non-polar organic solvent instead of a two-phase system with aqueous bicarbonate. With an excess (1/3 equivalents) of triphosgene, acetyl migratory product was minimized, and formation of the tetrasubstituted urea also ceased, but the yield of the interesting carbamoyl chloride $\mathbf{5 6}$ increased to $67 \%$. It was successfully isolated by column chromatography on normal $\mathrm{SiO}_{2}$, by elution with isopropyl ether. ${ }^{81,82,94-96}$ 

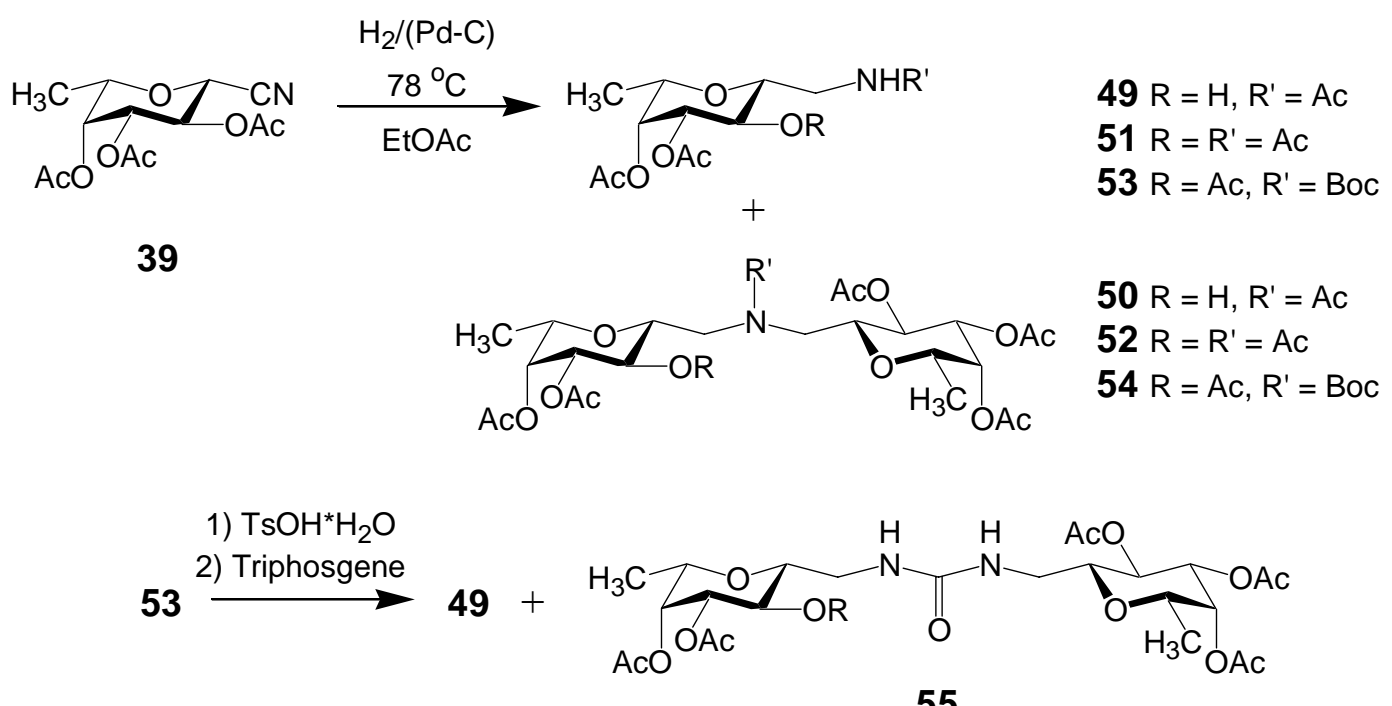

55

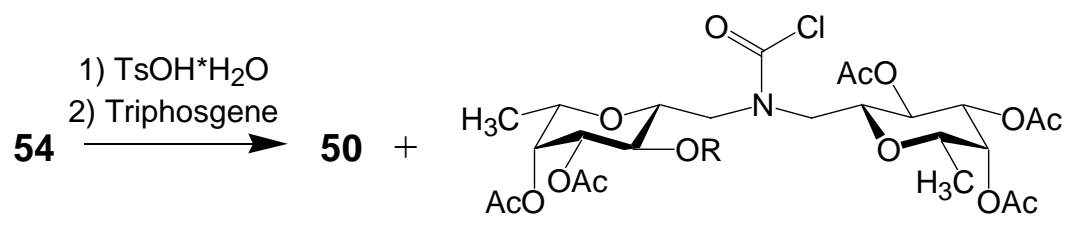

56

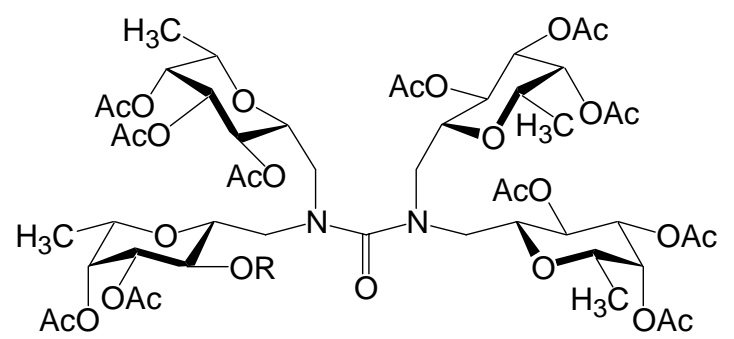

57

Scheme 8. Reduction of glycosyl cyanides, and further transformations of the products. ${ }^{81,82,94-96}$

Scheme 8 summarizes the synthetic possibilities for the two readily obtainable Boc-aminomethyl saccharides 53 and 54. The utility of compounds 53, 54, and 56 is readily appreciated, for attaching stable $\beta$-L-fucopyranosyl residues via amide, urethane, or urea bonds to carboxyl, hydroxyl, or amino groups of proteins or other biological scaffolds, to produce e.g. "neoglycoproteins." This methodology should be extendable to other sugars.

We have shown that $O$-acetyl protective groups are removable under very mild conditions, with $\mathrm{NEt}_{3} / \mathrm{MeOH} / \mathrm{H}_{2} \mathrm{O}$. ${ }^{100}$ The base and the byproduct $\mathrm{AcOH}$ are smoothly removed by azeotropic water vapor distillation in vacuo, or presumably also by freeze drying, without damage to delicate biochemical substrates. 


\section{Henry Condensation}

One of the most common methods for the chain extension of carbohydrates is the Henry condensation of pentoses and hexoses with nitromethane in the presence of a strong base. In 1946 Sowden and Fisher condensed 4,6-O-benzylidene-D-glucopyranose 59 (Scheme 9) with nitromethane in the presence of methoxide to give D-heptitol $\mathbf{6 0}$ and nitromethyl $\beta$-D-glucopyranoside 63 in 21\% and 5\% yield, respectively. ${ }^{101}$ Later, Petrus et. al. improved the total yields of unprotected nitromethyl D-hexopyranosides, but their approach is lengthy and complicated, requires careful workup with adjustment of $\mathrm{pH}$, and produces isomeric mixtures. ${ }^{102}$ Strong bases $\left(\mathrm{HO}^{-}, \mathrm{MeO}^{-}\right)$in these procedures in protic solvents lead to open-chain products (i.e. 60, Scheme 9). ${ }^{101}$ Their hot dehydration gives cyclic forms, reverting only very slowly to acyclic at low temperatures. ${ }^{103}$ Presumably, acyclic forms, having more hydroxy groups, are stabilized by solvation in protic solvents.

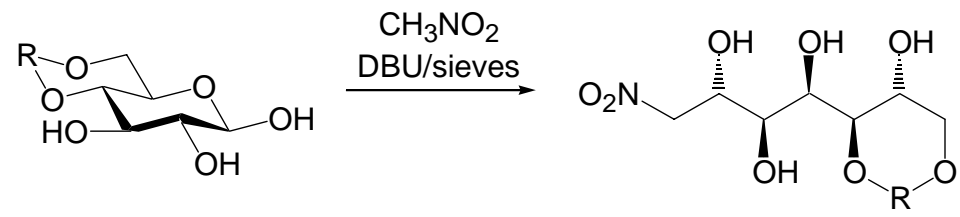

$58 \mathrm{R}=\mathrm{H}, \mathrm{H}$

$60 \mathrm{R}=\mathrm{PhCH}$

$59 \mathrm{R}=\mathrm{PhCH}$

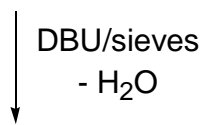<smiles>O=[N+]([O-])CC(C[N+](=O)[O-])C(O)C(O)C1OPOCC1O</smiles>

$64 \mathrm{R}=\mathrm{PhCH}$

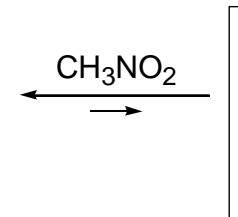

$\left[\begin{array}{l}\mathrm{O}_{\mathrm{R}^{-}} \\ \mathrm{O}\end{array}\right]$

$61 \mathrm{R}=\mathrm{PhCH}$
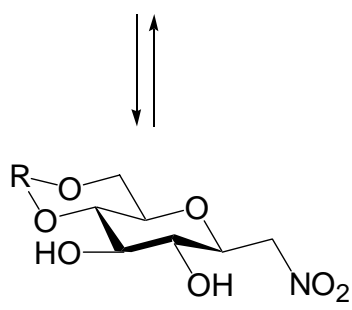

$62 \mathrm{R}=\mathrm{H}, \mathrm{H}$

$63 \mathrm{R}=\mathrm{PhCH}$

Scheme 9. Henry condensation of protected and unprotected $\beta$-D-glucopyranose. ${ }^{82,104-107}$

We had synthesized ${ }^{82,104-107}$ directly the cyclic compounds in aprotic solvents with a highly active bifunctional $^{108}$ catalyst 2-hydroxypyridine ${ }^{109}$ and DBU/molecular sieves ${ }^{104}$ with an improved yield of $77 \% .{ }^{105}$ We avoided protic solvents because of the strong basicity of DBU, 
which would provide just another way of creating $\mathrm{RO}^{-}$in $\mathrm{ROH}$. The cyclic product 63 was produced in a single step along with two minor byproducts $\mathbf{6 0}$ and $\mathbf{6 4} .^{104}$

We reinvestigated later $^{82,106,107}$ our original condensation ${ }^{104,105}$ of nitromethane with 4,6-O-benzylidene-D-glucopyranose 59 to nitromethyl 4,6-O-benzylidene $\beta$-D-glucopyranoside 63 and discovered that 2-HP was unnecessary. A time study, with careful TLC analysis and flash chromatography of the reaction mixture with DBU and molecular sieves revealed sequential products, which are conveniently explained as outlined in the mechanistically simplified Scheme 9.

The condensation progressed similarly in THF and dioxane, with 4,6-O-benzylideneD-glucopyranose via 5,7-O-benzylidene-1-deoxy-1-nitro-D-glycero-D-gulo-heptitol 60, which subsequently changed into nitromethyl $\beta$-D-glucopyranoside 63. The former was observed accumulating before being further converted during at least 50 hours at room temperature to the cyclic product 63, along with some 5,7-O-benzylidene-1,2-dideoxy-1-nitro-2-nitromethylD-gluco-heptitol 64, in yields similar to those already reported. ${ }^{104,105}$ In THF or dioxane, accumulation of the final acyclic product $\mathbf{6 4}$ was dependent on temperature, time, and solvent: less decomposition was observed in dioxane. In these condensations, we could not determine if the presence of 2-HP had any effect at all, at any stage of the reaction. In any case, the first heptitol 60 and the desired 63 were kinetically controlled intermediates, which, given enough time, were transformed into the "thermodynamic" product 64, by a still slower overall rate.

When similar conditions were employed for unprotected D-glucose 58, there was no reaction for prolonged periods of time. Heating only resulted in almost complete decomposition. This was expected since unprotected sugars are typically not very soluble in THF or dioxane. But in acetonitrile, pyridine or a mixture of these at $50{ }^{\circ} \mathrm{C}$, the condensations were fairly clean. ${ }^{82,106,107}$ The condensation progressed to completion within one day, and only nitromethyl $\beta$-Dglucopyranoside 62 (Scheme 9) was detected and isolated when 5:1 acetonitrile/pyridine (38\% yield) or pyridine was used as the solvent (57\% yield). For completion and maximal yield, a stoichiometric amount of DBU was needed.

Condensations with L-fucose 65 were monitored by TLC and flash chromatography, and gave sequential products as outlined in Scheme $10 .^{82,106,107}$ Within $12 \mathrm{~h}$ in THF more than half of the starting L-fucose was converted into corresponding 1,6-dideoxy-1-nitro-L-glycero-D-mannoheptitol 66. By the end of day 3, most of L-fucose had been transformed into the acyclic heptitol 66, and the subsequent conversion into cyclic nitromethyl $\beta$-L-fucopyranoside 67 was followed for another 5 days, during which time a significant portion of the desired cyclic product $\mathbf{6 7}$ had also been slowly converted into 1,1,6-trideoxy-1-nitro-2-nitromethyl-L-galacto-heptitol 68. Thus, the maximal yield for product $\mathbf{6 7}$ required minimizing decomposition and the yields of $\mathbf{6 6}$ and 68. In dioxane, only 67 was isolated as the product ( $62 \%$ ). On the contrary, $50 \% 68$ vs. $5 \% 67$ were obtained in DMF. The results suggest that solubility might be the most important factor to affect Henry condensations of unprotected sugars. 


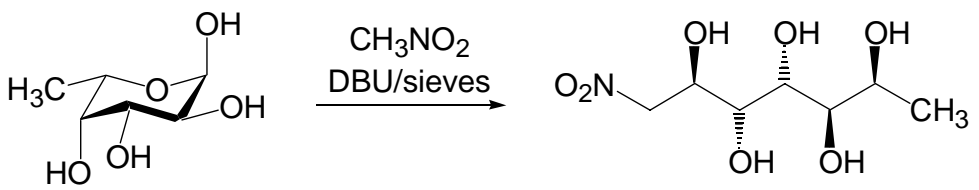

65

66

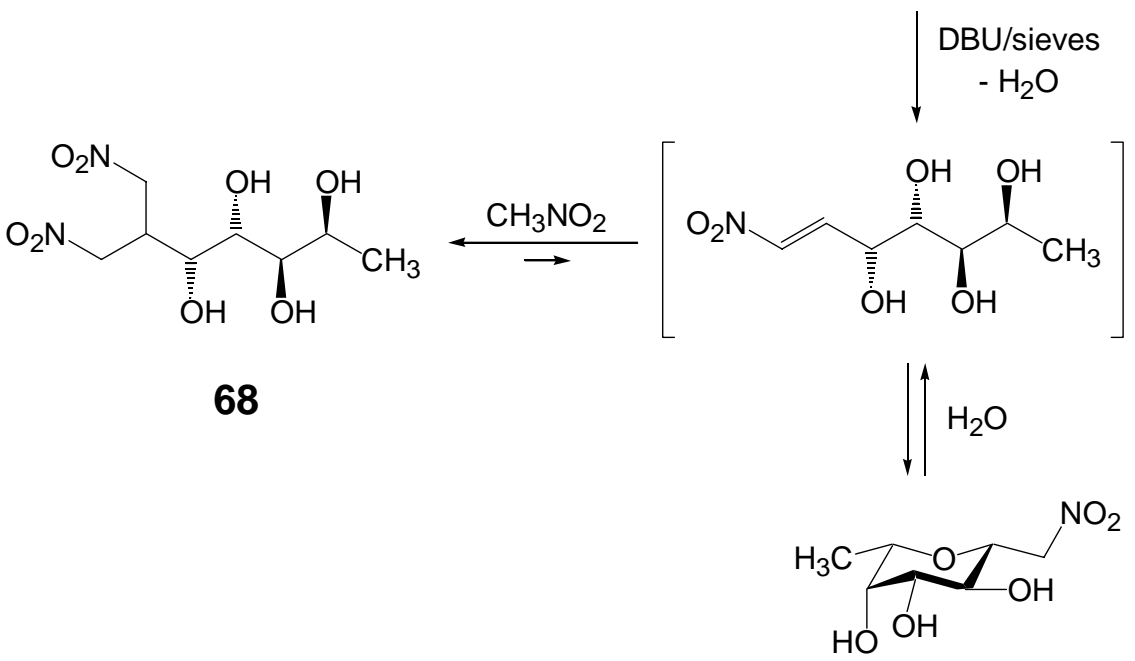

67

Scheme 10. Henry condensation of unprotected L-fucose $65^{82,106,107}$

A possible further transformation of the synthesized nitro-compounds is illustrated by the reduction of nitromethyl $\beta$-D-glucopyranoside 63 with a specially prepared elemental iron in water/THF under $\mathrm{CO}_{2}$ atmosphere to aminomethyl-C-glucopyranoside 69 (Scheme 11). ${ }^{104,105}$

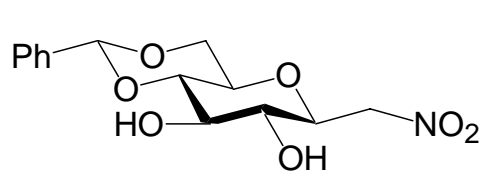

63

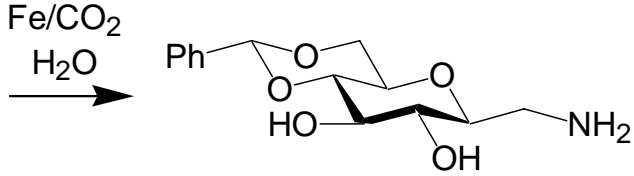

69

Scheme 11. Reduction of the Henry condensation product 63 to the aminomethyl-C-glycoside 69.

\section{Condensation with Malononitrile}

As described above, Henry condensation with nitromethane of partially protected and nonprotected pyranoses with a free anomeric hemiacetal function in presence of DBU and molecular sieves produces $C$-glycosides, which molecules incorporated one or two molecules of 
nitromethane (an example of L-fucose reaction is shown on Scheme 10). The ratio of products substantially depended on conditions of the reaction. ${ }^{82,104-107}$

Inspired by this result, we explored a possibility of a similar synthesis of $C$-glycosides using malononitrile ( $\mathrm{MN}$ ) instead of nitromethane as an active methylene component (Scheme 12). ${ }^{110,111}$ Malononitrile is a versatile compound of exceptional reactivity. ${ }^{12,113}$ It is often used as a reactant for synthesis of heterocycles since the methylene group and either one or both cyano groups can take part in condensation reactions to give a variety of addition products and heterocyclic compounds. ${ }^{114-116} \mathrm{MN}$ has not been used for preparation of $C$-glycosides, though their formation using dialkyl malonates was studied extensively. ${ }^{117}$

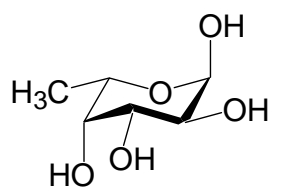

65

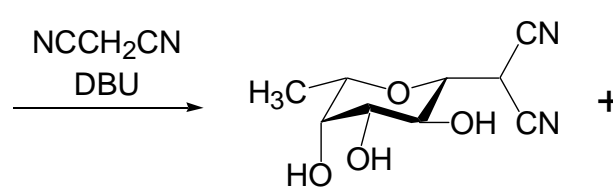

70<smiles>C[C@H](O)[C@@H](O)[C@@H](O)[C@H](O)C(C(C#N)C#N)C(C#N)C#N</smiles>

71

Scheme 12. Expected products from the reaction of L-fucose with malononitrile.

L-Fucose 65 was selected as a starting carbohydrate. We expected products similar to those obtained in reaction with nitromethane (Scheme 10). However, the reaction was much faster $(1 \mathrm{~h}$ instead of several days), and neither mono-adduct 70 nor bis-adduct 71 (Scheme 12), which are analogs of 67 and 68 (Scheme 10), was obtained. Instead, two cyclic compounds 73 (oil) and 74 (white crystals) in a ratio $\sim 5: 1$ (by NMR) were isolated by a column chromatography of the reaction mixture (Scheme 13). ${ }^{110,111}$ 


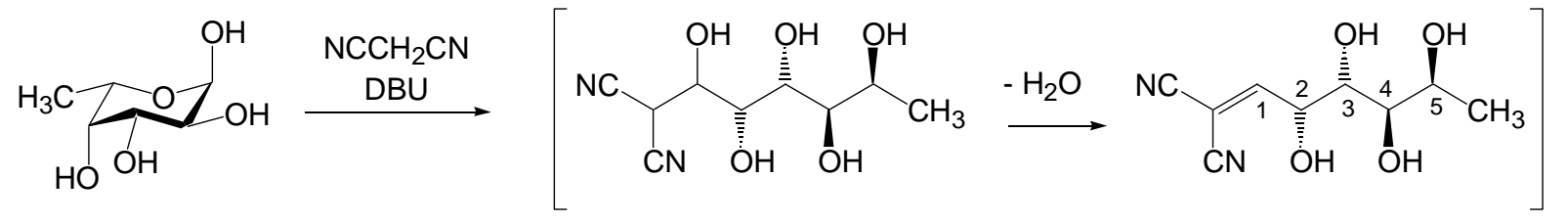

65

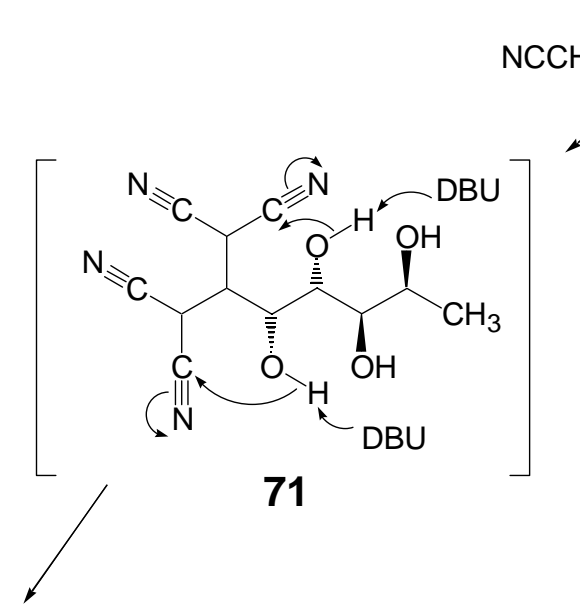<smiles>C[C@@H](O)[C@@H](O)[C@H]1OC(N)=C(C#N)[C@@H](C(C#N)C#N)[C@H]1O</smiles>

$73 a$<smiles>CC(C#N)[C@@H]1C(C#N)=C(N)O[C@@H]1[C@H](O)[C@H](O)[C@H](C)O</smiles>

73<smiles>C[C@H](O)[C@@H](O)[C@H]1OC(N)=C(C#N)[C@H]2C(C#N)=C(N)O[C@H]21</smiles>

74

Scheme 13. Condensation of L-fucose and malononitrile in presence of DBU.

The bicyclic structure $\mathbf{7 4}$ was proven by X-ray crystallography (Figure 6). ${ }^{110,118}$ Interestingly, the solution conformation (in $\mathrm{CD}_{3} \mathrm{OD}$ ) of the side chain in $\mathbf{7 4}$ estimated from the vicinal spin-spin couplings in ${ }^{1} \mathrm{H}$ NMR correlated well with the crystal structure data. ${ }^{111}$ To the best of our knowledge, no compounds have been described so far with this combination of fiveand six-membered oxygen-containing heterocycles. 

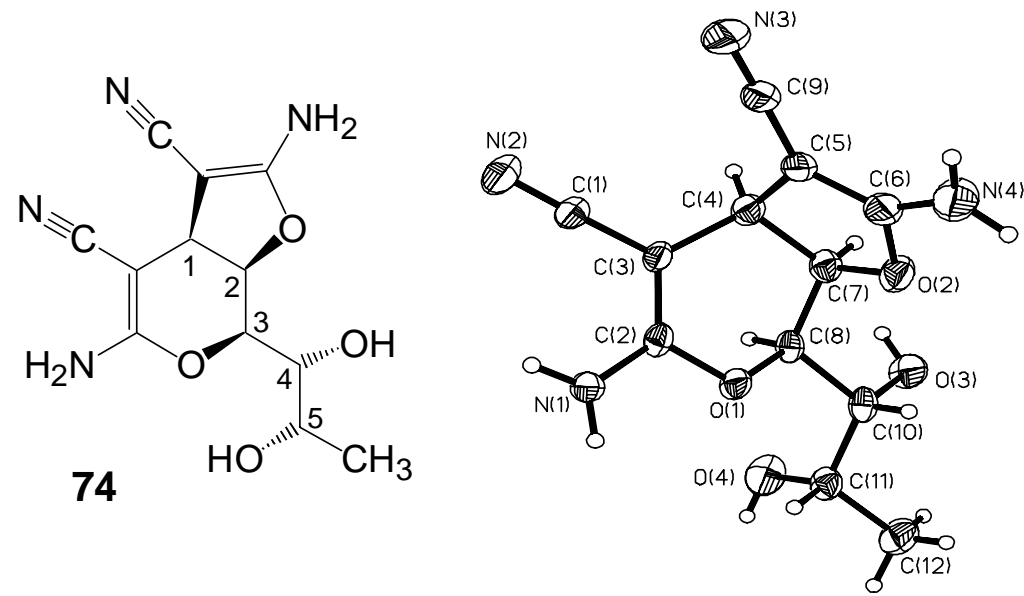

Figure 6. Molecular structure of the bicyclic product $74 .^{110,118}$

The results of the synthesis may be rationalized as a sequence of (a) Knoevenagel condensation producing intermediate 72, then (b) Michael addition of another MN resulting in formation of bis-adduct 71, and then (c) a base-induced double cyclization. The latter can occur via either the dihydrofuran derivative 73, or the dihydropyran derivative 73a. However, we isolated only one monocyclic compound, which structure could not be assigned based on NMR data. In an attempt to prepare a crystalline derivative appropriate for X-ray analysis, we acetylated product 73 (Scheme 14) and obtained the furan derivative 75, which NMR parameters perfectly matched the parameters of similar furan derivatives described in literature. ${ }^{119}$ This result suggests the structure $\mathbf{7 3}$ as the intermediate monocyclic compound isolated in the reaction of L-fucose with MN. ${ }^{110,111}$

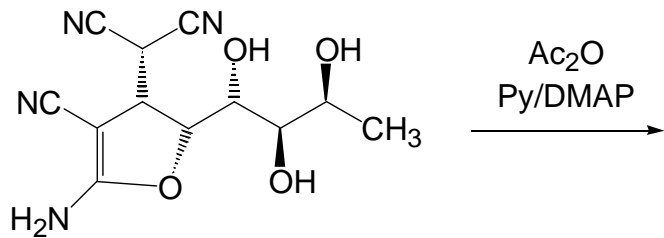

73<smiles>CC(=O)Nc1oc([C@@H](OC(C)=O)[C@H](OC(C)=O)[C@@H](C)OC(C)=O)cc1C#N</smiles>

75

Scheme 14. Acetylation of monocylic compound 73.

\section{Total Syntheses of Aminomethyl-C-dideoxyglycopyranosides and their Quinamides}

The great majority of methods developed for the synthesis of $C$-glycosides ${ }^{18-20}$ start from natural sugars, mostly D-glucose, D-mannose and D-galactose, which are commercially available in 
multigram quantities. ${ }^{120}$ Other D-monosaccharides and all L-monosaccharides are very expensive and available only on a milligram scale. ${ }^{120}$ Moreover, D-gulose, D-altrose and D-idose exist in appreciable proportions as their 1,6-anhydrides with essentially different chemical behaviour. ${ }^{121}$ We developed an approach to the total syntheses of partially functionalized $\beta-C$ glycopyranosides, ${ }^{49,93,122-128}$ related to 2,4- and 4,6-dideoxyhexoses, found as cardiac glycosides. ${ }^{129,130}$ These $C$-glycosides are tetrahydropyrans obtained from homoallylic alcohols and acetals by a Lewis acid promoted cyclization, followed by dehydrohalogenation and subsequent double bond functionalization. ${ }^{49,93,122-128}$ A subsequent use of these building blocks for the syntheses of di- and oligosaccharide mimics is illustrated by their quinoylation. Quinic acid is an important structural component in a number of naturally occurring biologically active compounds which exhibit HIV-integrase inhibition, ${ }^{131-133}$ as well as hypocholesterolemic, ${ }^{134}$ hepatoprotective $^{135}$ and antioxidative ${ }^{136-138}$ activities. A combination of racemic aminomethyl $C$ glycosides with chiral quinic acid may directly yield biologically active chiral compounds.

Acid catalyzed reactions between homoallylic alcohols and aldehydes or acetals have been used before for the preparation of 2,6-disubstituted di- and tetrahydropyran derivatives (see Ref. 92 and references therein). We chose an expandable two-component scheme of cyclization with a possibility of various functional groups in readily available starting compounds. Use of phthalimido derivatives allowed for syntheses of (protected) aminomethyl $C$-glycopyranosides (Scheme 15).

Cyclizations of this type furnish exclusively cis-2,6-disubstituted tetrahydropyrans ${ }^{49,93,122-128}$ corresponding to the $\beta$-configuration of the projected $C$-glycopyranosides. Most $C$-glycoside syntheses provide $\alpha$-products. ${ }^{19,20}$ The new stereocenter $\mathrm{C}(6)$ is entirely determined by the configuration of the existing stereocenter in the homoallylic alcohol. Chiral homoallylic alcohols would give enantiomerically pure tetrahydropyrans, and finally $C$-glycosides. We obtained racemic aminomethyl $C$-glycosides, subsequently acylated with the chiral lactone of quinic acid 11 (Scheme 15), and separated as derivatives of diastereomeric quinamides (Scheme 16). 
<smiles>C=CCC(C)O</smiles>

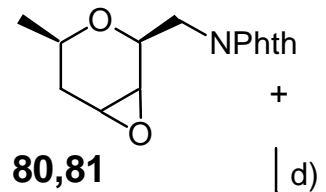<smiles>C[C@H]1O[C@H](C[NH2+]C(C)(Cl)Cl)CC2OC21</smiles><smiles>CC1CC=CC(C[NH2+][CH2+][C@H]2C=CCC(CNc3ccccc3)O2)O1</smiles>

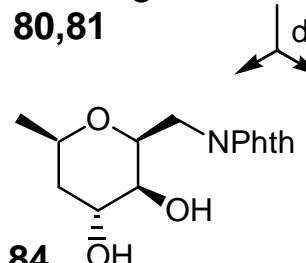

84 Ō $\mathrm{H}$

d)

82,83<smiles>C[C@H]1O[C@H](CNPCc2ccccc2)C[C@H](O)[C@@H]1O</smiles><smiles>[R]NC[C@H]1O[C@H](C)C[C@@H](O[R7])[C@H]1O[R]</smiles>

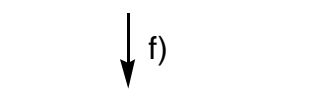

78<smiles>CC(C)=[13C](C)C</smiles>

79<smiles>[R]NC[C@H]1C[C@@H]([R2])[C@@H]([R6])[C@@H](C)O1</smiles><smiles>[R]C(=O)NC[C@H]1O[C@H](C)C[C@H](O)[C@H]1O</smiles>

+ diastereomer

$\mathbf{9 7 , 9 8}$<smiles>[R]C(=O)NC[C@H]1C[C@@H](O)[C@@H](C)[C@H](C)O1</smiles>

+ diastereomer

99,100<smiles>C[C@H]1C[C@H](C)[C@@H](O)[C@@H](CNPc2ccccc2)O1</smiles><smiles>[18OH][18OH]</smiles><smiles>CC1OC(CNP)C[C@H](C)[C@H]1O</smiles><smiles>[V][V]</smiles>

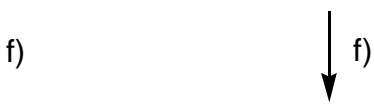<smiles>[R]NC[C@H]1O[C@H](C)C[C@@H](O)[C@@H]1[R]</smiles><smiles>[R]NC[C@H]1C[C@@H]([R2])[C@@H]([R20])[C@@H](C)O1</smiles><smiles>CC(C)(C)C1(O)CC(O)(C(=O)O)CC(O)C1O</smiles>

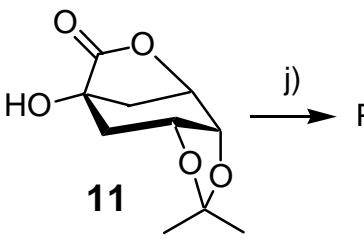<smiles>[R]C(=O)NC[C@H]1O[C@H](C)C[C@H](O)[C@H]1O</smiles>

+ diastereomer

100,101

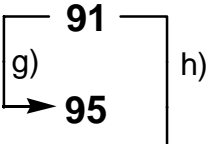<smiles>[R]C(=O)NC[C@H]1C[C@H](O)[C@@H](O)[C@@H](C)O1</smiles>

+ diastereomer

102,103

Scheme 15. Synthesis of aminomethyl- $C$-glycosides and their quinamides (76-83: stereoisomeric

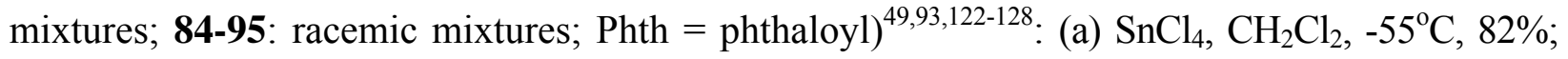
(b) DBU, LiCl, Py, reflux, 79\%; (c) Urea- $\mathrm{H}_{2} \mathrm{O}_{2}$, TFAA, 93\%; (d) TFA, $\mathrm{H}_{2} \mathrm{O} / \mathrm{THF}, 60^{\circ} \mathrm{C}, 74 \%$; (e) $\mathrm{OsO}_{4}, \mathrm{NMO}, 64 \%$; (f) 1) $\mathrm{Me}_{2} \mathrm{NH}, \mathrm{MeOH}, \mathrm{H}_{2} \mathrm{O}, 2$ ) $\left.\mathrm{H}_{2} \mathrm{SO}_{4}, \mathrm{H}_{2} \mathrm{O}, 3\right) \mathrm{NH}_{4} \mathrm{OH}, 80-86 \%$ (88-91: $\mathrm{R}=\mathrm{H}$ ); (g) $\mathrm{Ac}_{2} \mathrm{O}$, DMAP, Py, 51-85\% (92-95: $\left.\mathrm{R}=\mathrm{Ac}\right)$; (h) 11, DMA, 70 $\mathrm{C}, 58-77 \%$; (i) acetone, $p$ - TsOH, reflux, $86 \%$; (j) $\mathrm{BnNH}_{2}$, DMA, $55^{\circ} \mathrm{C}, 72 \%$. 


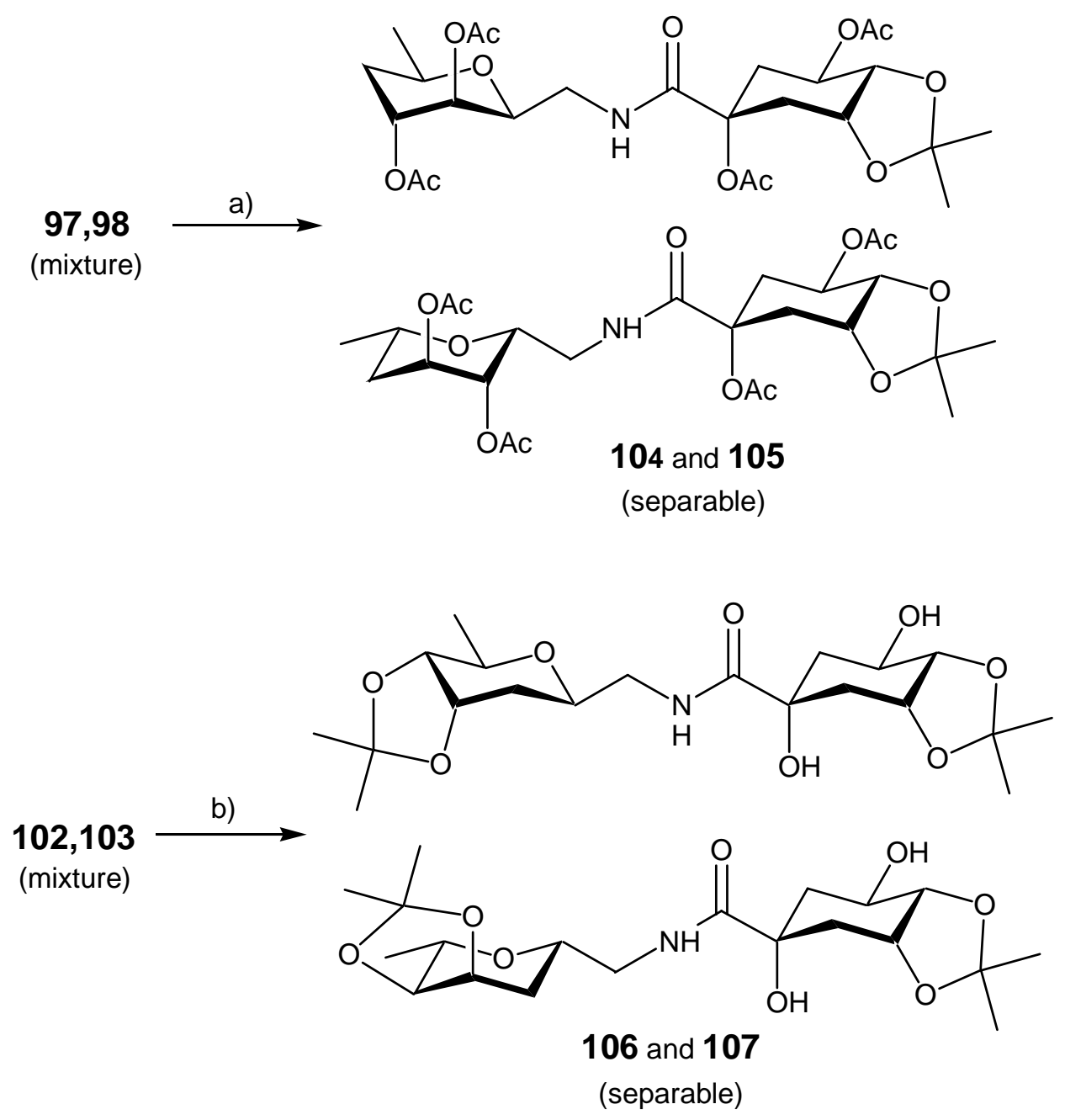

Scheme 16. Separation of diastereomeric mixtures of quinamides as isopropylidene-tetra- $O$ acetyl or diisopropylidene derivatives: (a) $\mathrm{Ac}_{2} \mathrm{O}$, DMAP, Py; (b) 2-methoxypropene, $p$-TsOH, DMF. ${ }^{49,128}$

Specifically for the synthesis of various homoallylic alcohols (Scheme 15), we developed new methods: transallylation ${ }^{139}$ and allylation in aqueous phase ${ }^{140,141}$ of commercially available and relatively stable aldehyde acetals. Acid promoted cyclization of pent-4-en-2-ol with the phthalimido derivative of 2,2-diethoxyethylamine at $-55^{\circ} \mathrm{C}$ in $\mathrm{CH}_{2} \mathrm{Cl}_{2}$ solution with $\mathrm{SnCl}_{4}$ (Scheme 15) gave chlorotetrahydropyrans 76 and 77 (5:1, separable by column chromatography). The alkenes 78, 79 were obtained as a 2:1 mixture (by NMR) by heating of the mixture 76, 77 with $\mathrm{DBU}$ in pyridine in presence of $\mathrm{LiCl}$, which facilitated in situ isomerization of equatorial into axial halogen, suitable for trans-elimination. Epoxidation of the alkene mixture with the urea- $\mathrm{H}_{2} \mathrm{O}_{2}$ complex in presence of $\left(\mathrm{CF}_{3} \mathrm{CO}\right)_{2} \mathrm{O}$ (TFAA $)^{142}$ produced an epoxide mixture 80-83 (93\%), which was difficult to separate. However, the well known tendency of epoxides to open trans-diaxially, ${ }^{143}$ allowed for direct synthesis of a two-component trans-diol mixture 84, 
85, separated by column chromatography (51\% and $23 \%$ respectively). After cis-dihydroxylation $\left(\mathrm{OsO}_{4} / \mathrm{NMO}\right)$ of the mixture 78, 79, only compounds 86 and 87 were isolated $(45 \%$ and $19 \%$ respectively).

Thus, we obtained a series of four racemic phthalimido-protected aminomethyl C-dideoxyglycopyranosides 84-87, which produced with aq. $\mathrm{Me}_{2} \mathrm{NH}^{144}$ the dimethylammonium salts of phthalamic acids. They were hydrolyzed after evaporation of excess $\mathrm{Me}_{2} \mathrm{NH}$ by heating with aq. $\mathrm{H}_{2} \mathrm{SO}_{4}\left(70^{\circ} \mathrm{C}\right)$, followed by extraction of phthalic acid with $\mathrm{CH}_{2} \mathrm{Cl}_{2}$ and $\mathrm{Et}_{2} \mathrm{O}$. Neutralization by $\mathrm{NH}_{3}$ aq. and subsequent evaporation followed by column chromatography gave compounds 88-91 (80-86\%), characterized and analyzed as their $\mathrm{N}$-acetyl- and/or $\mathrm{N}, \mathrm{O}$ triacetyl derivatives, and used as building blocks for pseudodisaccharides. Acylation of benzylamine with the isopropylidenated $\gamma$-lactone of quinic acid $\mathbf{1 1}{ }^{145,146}$ provided us with $\mathrm{H}^{1}$ NMR chemical shifts and coupling constants for the quinoyl part of compound 96. Similarly we converted racemic $C$-glycosides 88-91 into their quinamides 97-103 (i. e. into diastereomeric $C$ pseudodisaccharides; Scheme 15).

Generally, separation of diastereomeric pairs 97-103 could only be achieved via their derivatives (Scheme 16). Thus, the trans-dihydroxy aminomethyl $C$-glycosides 97, 98 were separated as their $O$-acetyl derivatives by flash chromatography to produce 104 (or 105)(7\%), 105 (or 104) (28\%), and 104+105 (32\%). Quinamides 102, 103 were isopropylidenated, and the mixture 106, 107 was enriched with one of the stereoisomers (9:1) by column chromatography.

\section{C-Glycosides via Cycloadditions}

The aqueous hetero-Diels-Alder reaction has been investigated by A. Lubineau et. al., ${ }^{147-151}$ for the synthesis of dihydropyran cyclo-adducts. We wanted to explore their use, through dihydroxylation of the double bond for syntheses of $C$-glycosides, ${ }^{152,153}$ as mimetics of naturally occuring 2,6-dideoxy sugars. ${ }^{154}$ Technical 1,3-pentadiene (piperylene) and aq. glyoxylic acid are inexpensive commercial products, which were used as starting materials. The reaction was regioselective in the intended way, most likely because of the electron donating property of the methyl group of pentadiene. The cis- and trans- acids were obtained in comparable amounts (Scheme 17). ${ }^{152,153}$ Their direct separation by chromatography was unsuccessful. However, methylation of the crude acid product 108, 109 rendered the mixture 110, 111 separable on TLC, and by column chromatography. In this way we obtained suitable starting materials for the following dihydroxylations. 

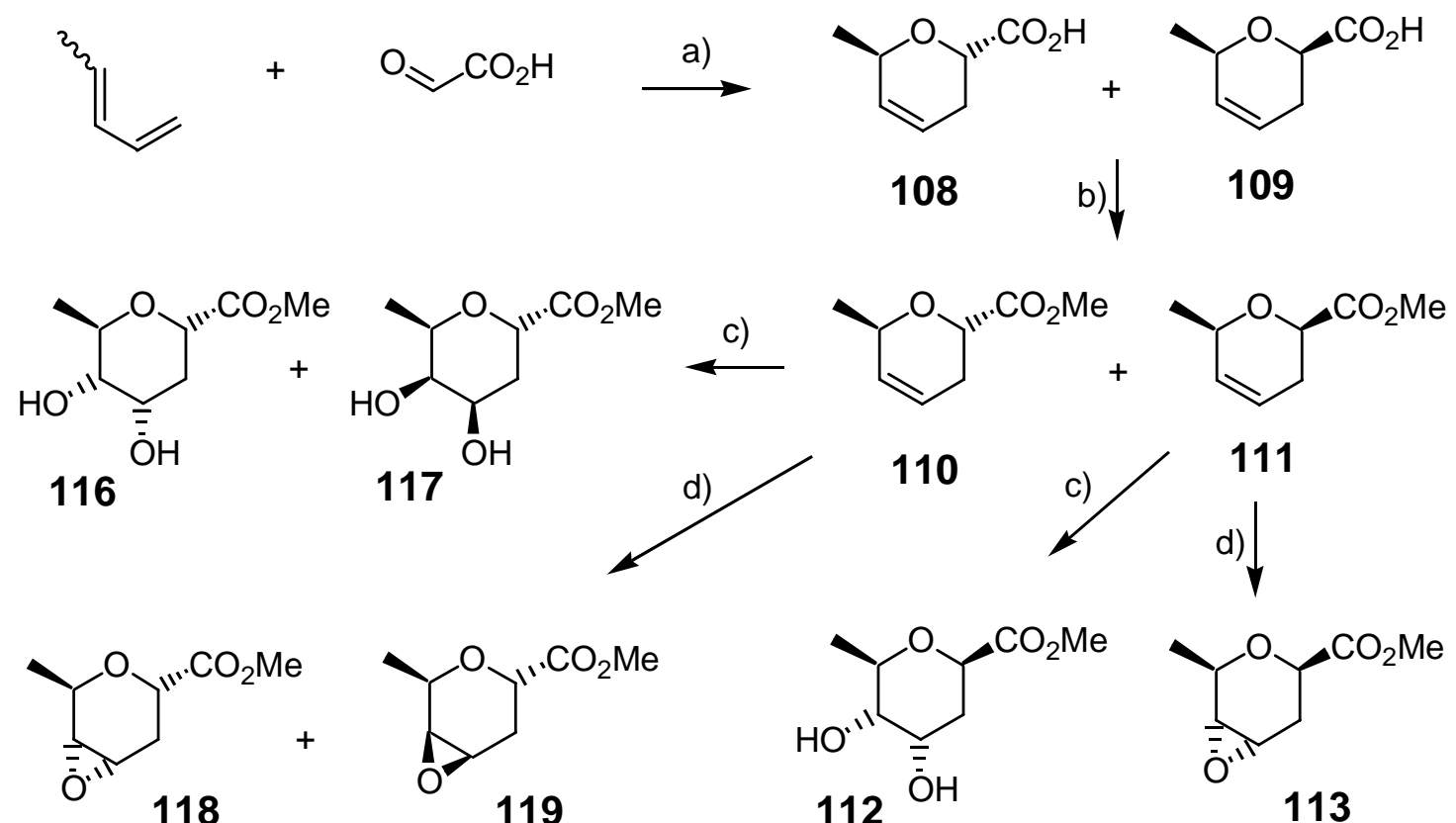

e),b) $\downarrow$<smiles>COC(=O)[C@H]1C[C@@H](O)[C@H](O)[C@@H](C)O1</smiles>

112<smiles>CC(=O)[C@H]1C[C@@H]2O[C@H]2[C@H](C)O1</smiles>

113

e)<smiles>CO[C@H]1C[C@@H](O)[C@@H](O)[C@@H](C)O1</smiles>

120
121<smiles>COC(=O)[C@H]1C[C@@H](O)[C@H](O)[C@@H](C)O1</smiles>

115

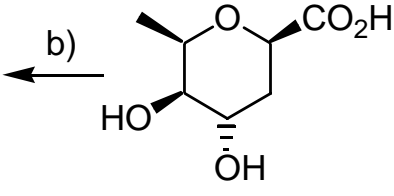

114

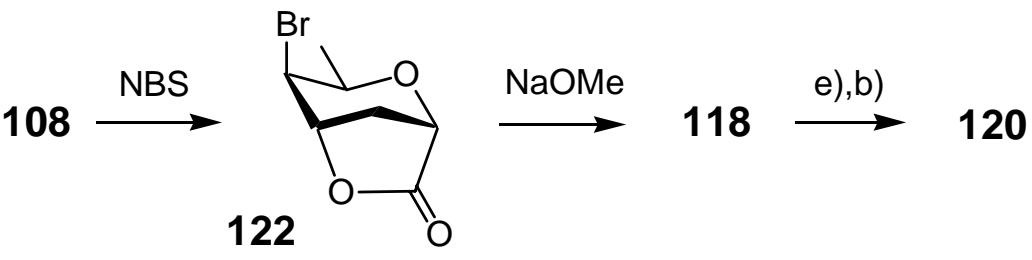

Scheme 17. Synthesis of 2,6-anhydro-2,4,5,6-tetrahydroxy-D,L-heptanoic acid esters: ${ }^{152,153}$ (a) $100^{\circ} \mathrm{C}, 56 \%$; (b) $\mathrm{CH}_{2} \mathrm{~N}_{2}$; (c) $\mathrm{OsO}_{4}, \mathrm{NMO}$; (d) Urea- $\mathrm{H}_{2} \mathrm{O}_{2}$, TFAA; (e) TFA/ $\mathrm{H}_{2} \mathrm{O}$.

The cis-isomer 111 gave only one major racemic product of cis-dihydroxylation (112). It is not clear why the molecule 111 does not allow $\mathrm{OsO}_{4}$ approach from both sides. Similarly, the epoxidation of 111 gave a crude epoxide 113 (Scheme 17) in 84\% yield, the NMR and TLC of which showed no evidence of the epoxide with opposite configuration. Its purification by column chromatography proved to be difficult, due to its instability. As expected, acid hydrolysis $(\mathbf{1 1 3} \rightarrow \mathbf{1 1 4})$ gave a single major product, which could be isolated pure after esterification to 115 
( $81 \%$ overall; Scheme 17). It is advantageous, that any "opposite epoxide" in the crude mixture also would give preferentially the same diaxial hydrolysis product $114 .{ }^{143}$

cis-Dihydroxylation of trans-isomer $\mathbf{1 1 0}$ gave a mixture of stereoisomeric $\mathbf{1 1 6}$ and $\mathbf{1 1 7}$ (ratio 3:1 by NMR; overall yield 73\%). Compound 116 was crystallized from the mixture (57\%). Compound 117 was not successfully isolated from the mother liquor, but its ${ }^{1} \mathrm{H}-\mathrm{NMR}$ parameters were determined from the mixture.

The epoxidation of trans-ester 110 gave two epoxides $\mathbf{1 1 8}$ and $\mathbf{1 1 9}$ as detected by TLC. Their mixture was subjected to hydrolysis and methylation to give a mixture of trans-dihydroxy esters 120 and 121, which was separated by column chromatography (yields $38 \%$ and $43 \%$ respectively).

We also tried to separate the carboxylic acids 108 and 109 by the reaction of NBS with their mixture. Only the trans-isomer 108 reacted with NBS to form a bromolactone, and the lactone 122 was easily separated from the reaction mixture, but the yield was too low (15-25\%). The nature of the side reaction of the trans-isomer with NBS could not be determined. The bromolactone 122 was cleaved by $\mathrm{NaOMe}$ to give the single epoxide 118 which was hydrolyzed to give a single carboxylic acid 120, providing another structure proof for it (Scheme 17).

Thus, the hetero-Diels-Alder reaction between inexpensive 50\% aq. glyoxylic acid and technical grade piperylene provided a starting point for synthesis of a series of 2,6-anhydro2,4,5,6-tetrahydroxy-D,L-heptanoic acid esters, ${ }^{152,153}$ which are $C$-glycosidic analogs of 2,6-dideoxypyranoses, prominent in cardiac glycosides. ${ }^{154}$

When racemate 112 and 4,6-O-benzylidene- $\beta$-D-glucopyranosyl methylamine $\mathbf{9 9}^{104}$ were refluxed in methanol in presence of a catalytic amount of $\mathrm{NaOMe}$, the reaction was completed in 3 hours, and produced the amide $\mathbf{1 0 0}(87 \%)$ as a mixture of diastereomers (Scheme 18). ${ }^{153}$

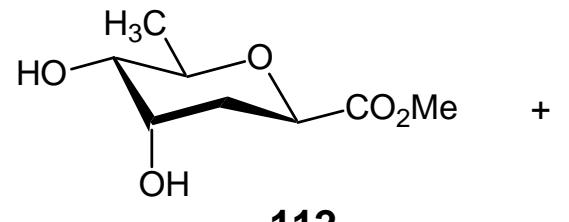

112

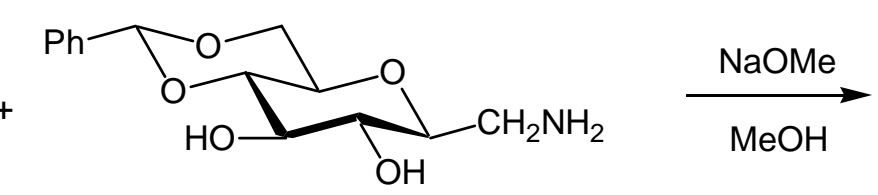

123

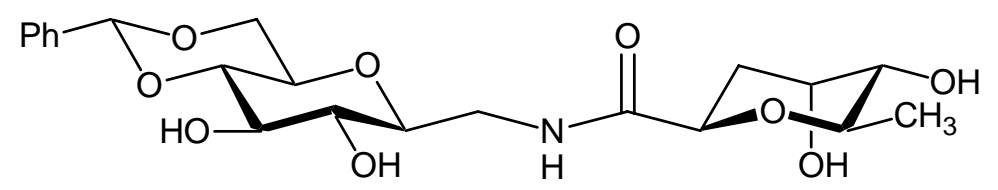

124

Scheme 18. Amide coupling of $\mathbf{1 1 2}$ with 123.

Such conjugates with natural carbohydrate derivatives offer potential for chiral resolution. Glycobiological applications for these compounds appear very possible. 


\section{Hydroxy-derivatives of 1,2-cyclohexanedicarboxylic Acids}

The structure of inhibitors usually resembles a substrate, a transition state, or a product of enzyme-catalyzed reaction. ${ }^{18-23}$ From this point of view, various polyhydroxylated five- and sixmembered cyclic compounds may be considered as monosaccharide structural analogs, and thus potential inhibitors of glycosidases. In a search for simple, readily accessible, but efficient glycosidase inhibitors, we designed, prepared, and assayed a series of cyclohexanecarboxylic acids and esters of types 125-131 with different substitution pattern, configuration, and length of $n$-alkyl groups $\mathrm{R}$, in order to reveal the effects of these parameters upon the inhibitory activity (Figure 7). ${ }^{11,155-158}$<smiles>[R]O[C@H]1CC[C@@H](O)[C@H](O)C1</smiles>

125<smiles>[R6]C1C[C@H](C(=O)O)[C@@H](C(=O)O)C[C@H]1O</smiles>

129<smiles>[R]O[C@H]1CC[C@@H](O)[C@H](O)C1</smiles>

126<smiles>[R6][C@H]1C[C@H](C(=O)O)[C@@H](C(=O)O)C[C@H]1O</smiles>

130<smiles>[R]OC(=O)[C@H]1C[C@H](O)[C@@H](O)C[C@H]1C(=O)O</smiles>

127<smiles>[R]OC(=O)[C@H]1C[C@H](O)[C@@H](O)C[C@H]1C(=O)O</smiles>

128<smiles>[R]OC1C[C@H](C(=O)O)[C@H](C(=O)O)C[C@H]1O</smiles>

131

Figure 7. Potential glycosidase inhibitors: cyclohexanecarboxylic acids and their esters. ${ }^{111,155-158}$ 


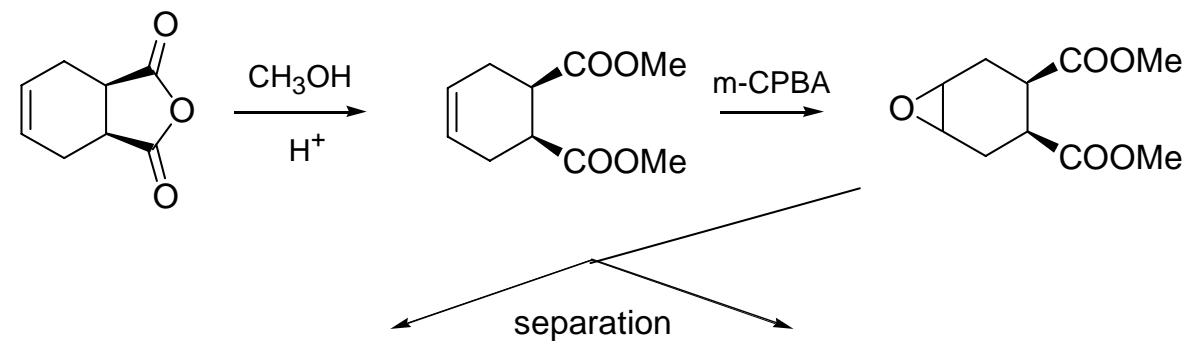

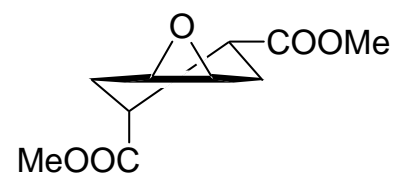

$\mathrm{ROH} \downarrow \mathrm{H}^{+}$<smiles>[R]OC(=O)C1CC2CC(C(=O)OC)C(C1)C2O</smiles>

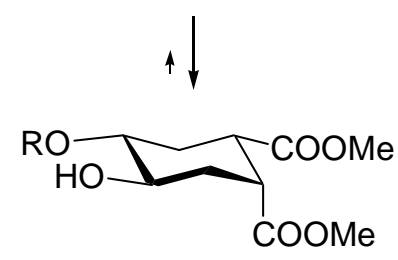

(1) $1 \mathrm{M} \mathrm{KOH} \downarrow$ (2) $\mathrm{H}_{3} \mathrm{O}^{+}$

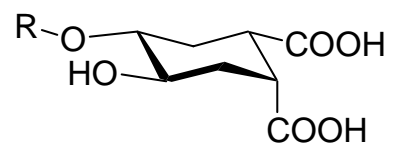

129a-I

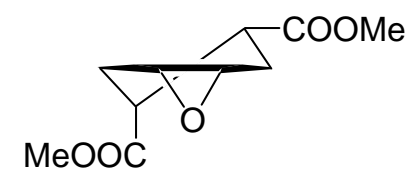

$n$-BuOH $\downarrow \mathrm{H}^{+}$
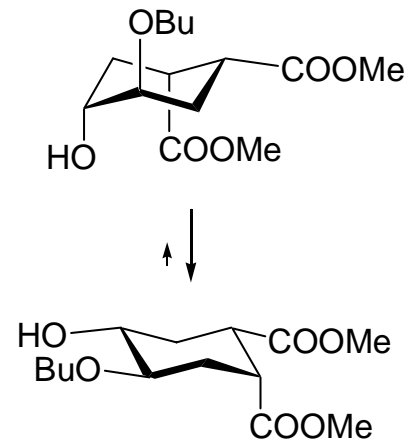

(1) $1 \mathrm{M} \mathrm{KOH} \downarrow$ (2) $\mathrm{H}_{3} \mathrm{O}^{+}$

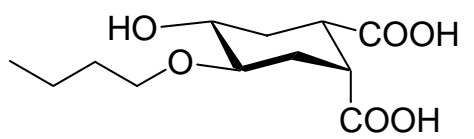

130

$\mathrm{R}=\mathrm{H}(\mathbf{a}), \mathrm{CH}_{3}(\mathbf{b}), \mathrm{Et}(\mathbf{c}), n-\mathrm{Pr}(\mathbf{d}), n-\mathrm{Bu}(\mathbf{e}), n-\mathrm{C}_{5} \mathrm{H}_{11}(\mathbf{f}), n-\mathrm{C}_{6} \mathrm{H}_{13}(\mathbf{g}), n-\mathrm{C}_{7} \mathrm{H}_{15}(\mathbf{h})$,

$n-\mathrm{C}_{8} \mathrm{H}_{17}(\mathbf{i}), n-\mathrm{C}_{9} \mathrm{H}_{19}(\mathbf{j}), n-\mathrm{C}_{10} \mathrm{H}_{21}(\mathbf{k}), n-\mathrm{C}_{12} \mathrm{H}_{25}$ (I)
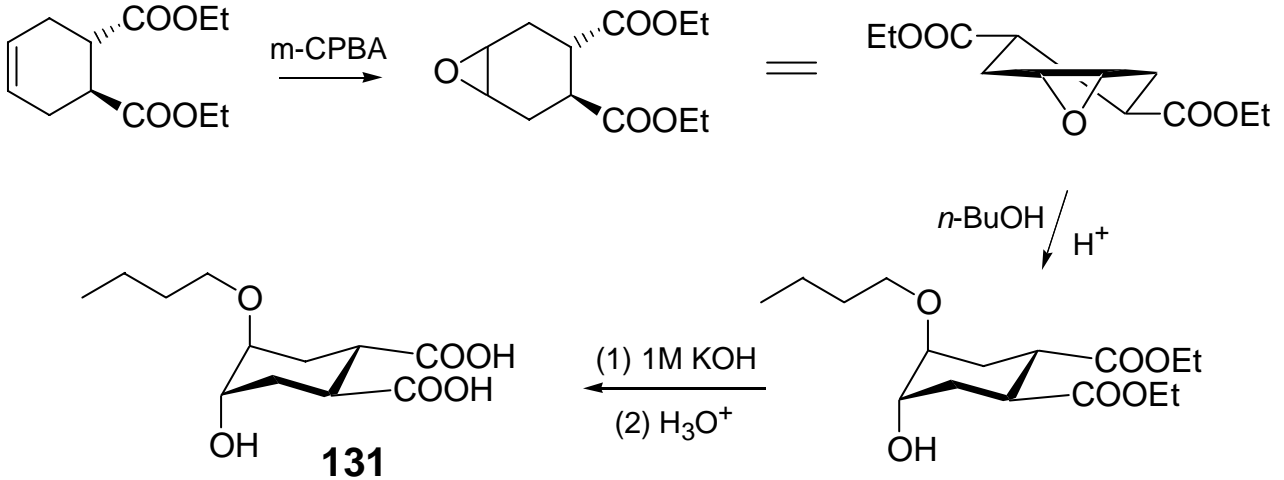

$\frac{\text { (1) } 1 \mathrm{M} \mathrm{KOH}}{(2) \mathrm{H}_{3} \mathrm{O}^{+}}$

$n-\mathrm{BuOH} / \mathrm{H}^{+}$

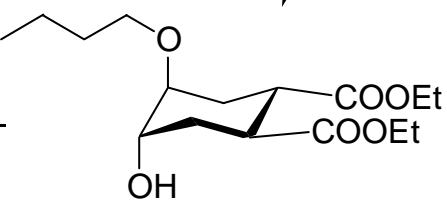

Scheme 19. Preparation of 4-HO-5-RO-1,2-cyclohexanedicarboxylic acids 129-131. ${ }^{111,155-158}$ 
The proposed structures contained a six-membered cycle and several hydrophilic groups, which is typical for many carbohydrate mimetics (see above). Alkyl groups were introduced to enhance the inhibiton. Such effect of lipophilic groups was observed previously ${ }^{18-23}$ for derivatives of 1-deoxynojirimycin and other iminosugars, alkyl glycosides, and some other glycosidase inhibitors. The preliminary tests against fungal glycosidases revealed only a weak to moderate inhibition of $\beta$-D-glucosidase by compounds $125(\mathrm{R}=\mathrm{H})$ and $127+128\left(\mathrm{R}=\mathrm{CH}_{3}, n\right.$ $\left.\mathrm{C}_{6} \mathrm{H}_{13}\right)$, and a weak inhibition of $\alpha$-L-fucosidase by compounds $\mathbf{1 2 5 + 1 2 6}$, and $\mathbf{1 2 7 + 1 2 8}(\mathrm{R}=$ $\left.\mathrm{CH}_{3}, \quad n-\mathrm{C}_{6} \mathrm{H}_{13}\right){ }^{111,155,156}$ However, very promising results were obtained for cyclohexanedicarboxylic acids of types 129-131. ${ }^{111,155-158}$ The synthesis of compounds 129-131 is presented in Scheme 19. It employed very simple starting compounds and reagents, and rather standard synthetic procedures.

These diacids were assayed for inhibitory activity against several glycosidases in multienzyme complexes isolated from fungi Penicillium canescens and Aspergillus oryzae. ${ }^{111,155-158}$ The inhibition was found to be specific with regard to the configuration of inhibitor, the type of enzyme, and even the particular source of enzyme. Most noticeably, these compounds inhibited $\alpha$ - and $\beta$-D-glucosidases. The isomers 130 and 131 appeared to be more selective inhibitors. It is worth mentioning that the compound 129e produced the same inhibition effect upon $\beta$-D-glucosidase from $A$. oryzae, as a $\sim 10$-fold higher concentration of methyldeoxynojirimycin.

The results of our studies proved that simple and readily available racemic derivatives of 1,2-cyclohexanedicarboxylic acid can be potent inhibitors for $\alpha$ - and $\beta$-D-glucosidases The presence of at least two carboxylic groups and one hydroxy group was found to be essential for efficient inhibition. Its magnitude depended on configuration of substituents and increased for $\beta$ glucosidase with lengthening of the inhibitor's alkoxy group. Further studies towards the enhancement of inhibitory activity may be focused on separation of enantiomers, on variation of the substituent configuration, of the length and structure of the lipophilic groups, and of the nature of heteroatoms. These compounds may be considered as promising precursors for combination with natural fragments (e. g. shikimic acid; see Sections 2, 7) for the synthesis of diastereomeric SCOMs.

\section{Acknowledgements}

We thank the Department of Chemistry of the University of the Pacific for financial support. Most of this work was described, as cited, in Ph.D. dissertations of K. Drew, X. Wang, A. Franz, P. Phiasivongsa, D. Gremyachinskiy, J. Lu, and B. Brazdova. 


\section{References and Notes}

1. Ferrier, R. J.; Blattner, R.; Field, R. A.; Furneaux, R. H.; Gardiner, J. M.; Hoberg, J. O. Kartha, K. P. R.; Tilbrook, D. M. G.; Tyler, P. C.; Wightman, R. H. Carbohydr. Chem. 2002, 33, 257.

2. Kotra, L. P.; Mobashery, S. Curr. Org. Chem. 2001, 5, 193-205.

3. Ferrier, R. J.; Blattner, R.; Clinch, K.; Furneaux, R. H.; Gardiner, J. M.; Tyler, P. C.; Wightman, R. H.; Williams, N. R. Carbohydr. Chem. 1996, 28, 251-262.

4. Mareel, M.; Leroy, A. Physiol. Rev. 2003, 83, 337-376.

5. Burleigh, B. A.; Woolsey, A. M. Cell. Microbiol. 2002, 4, 701-711.

6. Shi, X.; Friess, H.; Kleeff, J.; Ozawa, F.; Buechler, M. W. Pancreatology 2001, 1, 517-524.

7. Muramatsu, T. Glycoconjugate J. 2000, 17, 577-595.

8. Dwek, R. A. Chem. Rev. 1996, 96, 683-720.

9. Dwek, R., A.; Butters, T. D.; Platt, F. M.; Zitzmann, N. Nat. Rev. Drug Discov. 2002, 1, 65.

10. Wilson, I. B. H. Curr. Opin. Struct. Biol. 2002, 12, 569.

11. Crocker, P. R.; Feizi, T. Curr. Opin. Struct. Biol. 1996, 6, 679.

12. Crocker, P. R. Curr. Opin. Struct. Biol. 2002, 12, 609.

13. Harnett, W.; Harnett, M. M.; Byron, O. Curr. Prot. Pept. Sci. 2003, 4, 59.

14. Pendse, S.; Sayegh, M. H.; Frank, M. H. Curr. Drug Targets 2003, 4, 469.

15. Gagneux, P.; Varki, A. Glycobiology 1999, 9, 747.

16. Angata, T.; Varki, A. Chem. Rev. 2002, 102, 439.

17. Alper, J. Science 2003, 301, 159.

18. Chapleur, Y., Ed. Carbohydrate Mimics; Wiley-VCH: Weinheim, 1998.

19. Levy, D. E.; Tang, C. The Chemistry of C-Glycosides; Pergamon: Oxford, 1995.

20. Postema, M. H. D. C-Glycoside Synthesis; CRC Press: London, 1995.

21. Ernst, B.; Kolb, H. C.; Schwardt, O. In The Organic Chemistry of Sugars; Levy, D. E., Fügedi, P., Eds.; CRC Press: Boca Raton, 2006, pp 803-861.

22. Iminosugars: From Synthesis to Therapeutic Applications; Wiley: Chichester, 2007.

23. Iminosugars as Glycosidase Inhibitors: Nojirimycin and Beyond; Wiley-VCH: Weinheim, 1999.

24. Lundquist, J. J.; Toone, E. J. Chem. Rev. 2002, 102, 555.

25. Jayaraman, N.; Nepogodiev, S. A.; Stoddart, J. F. Chem. - Eur. J. 1997, 3, 1193.

26. Mammen, M.; Chio, S.-K.; Whitesides, G. M. Angew. Chem., Int. Ed. 1998, 37, 2755.

27. Dubber, M.; Lindhorst, T. K. J. Carbohydr. Chem. 2001, 20, 755.

28. Lindhorst, T. K. Glycoscience 2001, 3, 2393.

29. Svarovsky, S.; Barchi, J. J. In Book of Abstracts, 227th ACS National Meeting: Anaheim, CA, United States, 2004, p CARB 70.

30. Yamazaki, N.; Kojima, S.; Bovin, N. V.; Andre, S.; Gabius, S.; Gabius, H. J. Adv. Drug Deliv. Rev. 2000, 43, 225. 
31. Gross, P. H.; Samoshin, V. V.; Franz, A.; Gallagher, J.; Gremyachinskiy, D. E.; Lu, J.; Phiasivongsa, P.; Simo, O.; Wei, Y. Q. Glycobiology 2001, 11, 907.

32. Gross, P. H.; Franz, A. H.; Samoshin, V. V. In Recent Research Developments in Organic Chemistry; Pandalai, S. G., Ed.; Transworld Research Network: Trivandrum, 2004; Vol. 8, pp 255-280.

33. Fischer, H. O. L. Ber. 1921, 54B, 775-784.

34. Fischer, H. O. L.; Dangschat, G. Helv. Chim. Acta 1934, 17, 1200.

35. Fischer, H. O. L.; Dangschat, G. Helv. Chim. Acta 1935, 18, 1206.

36. Fischer, H. O. L.; Dangschat, G. Helv. Chim. Acta 1935, 18, 1204.

37. Jiang, S.; Singh, G. Tetrahedron 1998, 54, 4697.

38. Herrmann, K. M.; Weaver, L. M. Ann. Rev. Plant Physiol. Plant Mol. Biol. 1999, 50, 473.

39. Gonzalez-Bello, C.; Castedo, L. Med. Res. Rev. 2007, 27, 177-208.

40. Wilson, D. J.; Patton, S.; Florova, G.; Hale, V.; Reynolds, K. A. J. Industr. Microbiol. Biotechnol. 1998, 20, 299.

41. Sanchez-Sixto, C.; Prazeres, V. F. V.; Castedo, L.; Lamb, H.; Hawkins, A. R.; GonzalezBello, C. J. Med. Chem. 2005, 48, 4871.

42. Kim, C. U.; Lew, W.; Williams, M. A.; Zhang, L.; Liu, H.; Swaminathan, S.; Bischofberger, N.; Chen, M. S.; Tai, C. Y.; Mendel, D. B.; Laver, W. G.; Stevens, R. C. J. Am. Chem. Soc. 1997, 119, 681.

43. Bischofberger, N. W.; Kim, C. U.; Lew, W.; Liu, H.; Williams, M. A. PCT Int. Appl.; (Gilead Sciences, Inc., USA). Wo, 1996, p 345.

44. Eisenberg, E. J.; Bidgood, A.; Coundy, K. C. Antimicrob. Agents Chemotherapy 1997, 41, 1949.

45. Lagoja, I. M.; De Clercq, E. Med. Res. Rev. 2008, 28, 1.

46. Abdel-Ghafar, A.-N.; Chotpitayasunondh, T.; Gao, Z.; Hayden, F. G.; Nguyen, D. H.; de Jong, M. D.; Naghdaliyev, A.; Peiris, J. S. M.; Shindo, N.; Soeroso, S.; Uyeki, T. M. New England J. Med. 2008, 358, 261.

47. Nguyen, T. T. M.; Gross, P. H.; Franz, A. H. ARKIVOC 2005, (iv), 110.

48. Nguyen, Q. L.; Olmstead, L.; Bains, S.; Franz, A. H. ARKIVOC 2007, (xiii), 235.

49. Gremyachinskiy, D. E.; Samoshin, V. V.; Gross, P. H. Tetrahedron Lett. 2003, 44, 6587.

50. Gross, P. H.; Zimmerman, H. K. Liebigs Ann. Chem. 1964, 674, 211.

51. Trost, B. M.; Romero, A. G. J. Org. Chem. 1986, 51, 2332-2342.

52. Chiu, T. M. K.; Sigillo, K.; Gross, P. H.; Franz, A. H. Synth. Commun. 2007, 37, 2355.

53. Danishefsky, S. J.; Bilodeau, M. T. Angew. Chem., Int. Ed. 1996, 35, 1380.

54. Seeberger, P. H.; Danishefsky, S. J. Acc. Chem. Res. 1998, 31, 685.

55. Williams, L. J.; Garbaccio, R. M.; Danishefsky, S. J. Carbohydr. Chem. Biol. 2000, 1, 61.

56. Ramesh, N. G.; Balasubramanian, K. K. Eur. J. Org. Chem. 2003, 4477.

57. Taillefumier, C.; Chapleur, Y. Chem. Rev. 2004, 104, 263. 
58. Danishefsky, S. J.; Allen, J. R. Angew. Chem., Int. Ed. 2000, 39, 836.

59. Roth, W.; Pigman, W. Methods Carbohydr. Chem. 1963, 405.

60. Shafizadeh, F. Methods Carbohydr. Chem. 1963, 409.

61. El Khadem, H. S.; Swartz, D. L.; Nelson, J. K.; Berry, L. A. Carbohydr. Res. 1977, 58, 230.

62. Franz, A. H.; Wei, Y.; Samoshin, V. V.; Gross, P. H. J. Org. Chem. 2002, 67, 7662.

63. Franz, A.; Wei, Y. Q.; Samoshin, V. V.; Gross, P. H. Glycobiology 2001, 11, 907.

64. Franz, A. H. Oligosaccharide mimics: synthesis, characterization, and biological properties, Ph.D. Dissertation; University of the Pacific: Stockton, CA, USA, 2000.

65. Ferrier, R. J.; Prasad, N. J. Chem. Soc. C 1969, 581.

66. Franz, A. H.; Zhdankin, V. V.; Samoshin, V. V.; Minch, M. J.; Young, V. G.; Gross, P. H. Mendeleev Commun. 1999, 45.

67. Franz, A. H.; Gross, P. H. Carbohydr. Lett. 1997, 2, 371.

68. Franz, A.; Gross, P. In Book of Abstracts, 213th ACS National Meeting: San Francisco, USA, 1997, p CARB 090.

69. Gross, P. H.; Franz, A. H. In Book of Abstracts, 219th ACS National Meeting: San Francisco, USA, 2000, p CARB 034.

70. Helferich, B.; Bettin, K. L. Chem. Ber. 1961, 94, 1159.

71. Coxon, B.; Fletcher, H. G. J. J. Am. Chem. Soc. 1963, 85, 2637.

72. Coxon, B.; Fletcher, H. G. J. J. Am. Chem. Soc. 1964, 86, 922.

73. Coxon, B.; Hall, L. D. Tetrahedron 1964, 20, 1685.

74. Coxon, B. Ann. NY Acad. Sci. 1973, 952.

75. Myers, R. W.; Lee, Y. C. Carbohydr. Res. 1984, 132, 61.

76. Myers, R. W.; Lee, Y. C. Carbohydr. Res. 1986, 154, 145.

77. De Las Heras, F. G.; Fernandez-Resa, P. J. Chem. Soc., Perkin Trans. 1982, 903.

78. Utimoto, K.; Horiie, T. Tetrahedron Lett. 1982, 23, 237.

79. De las Heras, F. G.; San Felix, A.; Fernandez-Resa, P. Tetrahedron 1983, 39, 1617.

80. Utimoto, K.; Wakabayashi, Y.; Horiie, T.; Inoue, M.; Shishiyama, Y.; Obayashi, M.; Nozaki, H. Tetrahedron 1983, 39, 967.

81. Phiasivongsa, P.; Gallagher, J.; Chen, C.-N.; Jones, P. R.; Samoshin, V. V.; Gross, P. H. Org. Lett. 2002, 4, 4587.

82. Phiasivongsa, P. Synthesis of saccharomimetic fucopyranosyl-substituted urethanes and urea from glycopyranosyl methanes and cyanides. Ph.D.Dissertation; University of the Pacific: Stockton, CA, USA, 2002.

83. Phiasivongsa, P.; Samoshin, V. V.; Gross, P. H. In Book of Abstracts, XXIst International Carbohydrate Symposium: Cairns, Australia, 2002.

84. We thank Dr. Allen D. Hunter (Youngstown State University, Youngstown, Ohio, USA) for the X-ray crystallographic determination.

85. Cano, F. H.; Foces-Foces, C.; Bernabe, M.; Jimenez-Barbero, J.; Martin-Lomas, M.; Penades-Ullate, S. Tetrahedron 1985, 41, 3875. 
86. Betaneli, V. I.; Ovchinnikov, M. V.; Backinowsky, L. V.; Kochetkov, N. K. Carbohydr. Res. 1979, 68, C11-C13.

87. Kini, G. D.; Petrie, C. R.; Hennen, W. J.; Dalley, N. K.; Wilson, B. E.; Robins, R. K. Carbohydr. Res. 1987, 159, 81.

88. March, J. Advanced Organic Chemistry: Reactions, Mechanisms, and Structure, $4^{\text {th }}$ Ed.; Wiley: New York, 1992.

89. Yadav, J. S.; Reddy, B. V. S.; Chand, P. K. Tetrahedron Lett. 2001, 42, 4057-4059.

90. Hayashi, M.; Kawabata, H.; Shimono, S.; Kakehi, A. Tetrahedron Lett. 2000, 41, 2591.

91. Wei, Y. The chemistry of 2,3-unsaturated glycosyl cyanides, M.S. Thesis; University of the Pacific: Stockton, CA, USA, 1991.

92. Franz, A. H.; Samoshin, V. V.; Myers, C.; Hunter, A. D.; Gross, P. H. Carbohydr. Res. 2003, 338, 851.

93. Gross, P. H. Carbohydr. Polym. 1998, 37, 215.

94. Phiasivongsa, P.; Gallagher, J.; Chen, C.-N.; Jones, P. R.; Samoshin, V. V.; Gross, P. H. In Book of Abstracts, XXIst International Carbohydrate Symposium: Cairns, Australia, 2002.

95. Gross, P. H.; Phiasivongsa, P. In Book of Abstracts, 219th ACS National Meeting: San Francisco, USA, 2000, p CARB 36.

96. Phiasivongsa, P.; Chen, P.; Jones, P. R.; Samoshin, V. V.; Gross, P. H. Glycobiology 2001, $11,908$.

97. Brieger, G.; Nestrick, T. J. Chem. Rev. 1974, 74, 567.

98. Lentz, D. H.; Norris, G. E.; Taylor, C. M.; Slim, G. C. Tetrahedron 2001, 42, 4589.

99. Iwakura, Y.; Uno, K. J. Org. Chem. 1965, 30, 1158.

100.Gnichtel, H.; Rebentisch, D.; Tompkins, T. C.; Gross, P. H. J. Org. Chem. 1982, 47, 2691.

101.Sowden, J. C.; Fischer, H. O. L. J. Am. Chem. Soc. 1946, 68, 1511.

102.Petrus, L.; Bystricky, S.; Sticzay, T.; Bilik, V. Chemicke Zvesti 1982, 36, 103.

103.Koll, P.; Petrusova, M.; Petrus, L.; Kopf, J. Carbohydr. Res. 1993, 248, 349.

104.Drew, K. N.; Gross, Paul H. Tetrahedron 1991, 47, 6113.

105.Wang, X.; Gross, P. H. J. Org. Chem. 1995, 60, 1201.

106.Phiasivongsa, P.; Samoshin, V. V.; Gross, P. H. Tetrahedron Lett. 2003, 44, 5495.

107.Phiasivongsa, P.; Samoshin, V. V.; Gross, P. H. In Book of Abstracts, XXIst International Carbohydrate Symposium: Cairns, Australia, 2002.

108. Swain, C. G.; Brown, J. F. J. Am. Chem. Soc. 1952, 74, 2538.

109.Li, J. B. Aldrichim. Acta 1972, 5, 5.

110.Brazdova, B.; Phiasivongsa, P.; Nesterov, V. N.; Gross, P. H.; Samoshin, V. V. In Abstracts of Papers, 231st ACS National Meeting, Atlanta, GA, USA, 2006, pp CARB-050.

111. Brazdova, B. Synthesis and studies of carbohydrate mimetics as glycosidase inhibitors and molecular switches. Ph.D.Dissertation; University of the Pacific: Stockton, CA, USA, 2006.

112. Fatiadi, A. J. Synthesis 1978, 165.

113. Fatiadi, A. J. Synthesis 1978, 241. 
114.Freeman, F. Chem. Rev. 1969, 69, 591.

115. Mustafa, A. Furopyrans and Furopyrones; Interscience, 1967.

116.Katritzky, A. In Adv. Heterocycl. Chem., 1995; Vol. 6, pp 19-135.

117.Mikata, Y. M. Y.; Morioka, M.; Yano, S. Tetrahedron Lett. 2004, 45, 8785.

118. We thank Dr. Vladimir N. Nesterov (New Mexico Highlands University, Las Vegas, NM, USA) for the X-ray crystallographic determination.

119.Lankin, D. C.; Griffin, G. W.; Bernal, I.; Korp, J.; Watkins, S. F.; DeLord, T. J.; Bhacca, N. S. Tetrahedron 1984, 40, 2829-2836.

120.SIGMA Catalogue, 2006-2007.

121.Collins, P. M.; Ferrier, R. J. Monosaccharides: Their Chemistry and Their Roles in Natural Products; Wiley: New York, 1995.

122.Gross, P. H.; Suarez-Contreras, M.; Valdayo, M.; Gremyachinskiy, D. E.; Samoshin, V. V. In Book of Abstracts, 215th ACS National Meeting: Dallas, USA, 1998, p CARB 36.

123. Gremyachinskiy, D. E.; Samoshin, V. V.; I, K.; Gross, P. H. In Book of Abstracts, 19th International Carbohydrate Symposium: San Diego, USA, 1998.

124.Samoshin, V. V.; Gremyachinskiy, D. E.; Gross, P. H. Mendeleev Commun. 1999, 53.

125.Gross, P. H.; Gremyachinskiy, D. E.; Daher, M.; I, K.; Samoshin, V. V. In Book of Abstracts, 219th ACS National Meeting: San Francisco, USA, 2000, p CARB 35.

126.Gross, P. H.; Samoshin, V. V.; Franz, A.; Gallagher, J.; Gremyachinskiy, D. E.; Lu, J.; Phiasivongsa, P.; Wei, Y. Q. In Book of Abstracts, 9th Bratislava Symposium on Saccharides: Smolenice, Slovakia, 2000, pp 26-27.

127. Gremyachinskiy, D. E.; Samoshin, V. V.; Gross, P. H. Glycobiology 2001, 11, 908.

128. Gremyachinskiy, D. E. Total Synthesis of beta-Aminomethyl C-Glycosides and their Amides with Quinic Acid, Ph.D. Dissertation; University of the Pacific: Stockton, CA, USA, 2002.

129.Hoffmann, B. F.; Bigger, J. T., Jr. In The Pharmacological Basis of Therapeutics, 8th ed.; Gilman, A. G., Rall, T. W., Nies, A. S., Taylor, P., Eds.; Pergamon Press, Inc.: New York, 1990, pp 814-839.

130.Thomas, R.; Gray, P.; Andrews, J. Adv. Drug Res. 1990, 19, 312-562.

131.Robinson, E.; Reinecke, M.; Abdel-Malek, S.; Jia, Q.; Chow, S. Proc. Nat., Acad. Sci. USA 1996, 93, 6326.

132.Robinson, E.; Cordeiro, M.; Abdel-Malek, S.; Jia, Q.; Chow, S.; Reinecke, M.; Mitchell, W. Mol. Pharmacol. 1996, 50, 846.

133.Neamati, N.; Hong, H.; Sunder, S.; Milne, G.; Pommier, Y. Mol. Pharmacol. 1997, 52, 1041.

134.Montini, M.; Levoni, P.; Ongaro, A.; Pagani, G. Arzneim-Forsch. Drug. Res. 1975, 25, 1311.

135.Adzet, T.; Camarasa, J.; Laguna, J. J. Nat. Prod. 1987, 50, 612.

136. Gebhardt, R.; Fausel, M. Toxicol. In Vitro 1997, 11, 669.

137.Basnet, P.; Matsushige, K.; Hase, K.; Kadota, S.; Namba, T. Biol. Pharm. Bull. 1996, 19, 655. 
138.Slanina, J.; Taborska, E.; Bochorakova, H.; Slaninova, I.; Humpa, O.; Robinson, E.; Schram, K. Tetrahedron Lett. 2001, 42, 3383.

139. Watanabe, G. R.; Gremyachinskiy, D. E.; Gross, P. H.; Samoshin, V. V. J. Undergrad. Chem. Res. 2002, 1, 163.

140.Samoshin, V. V.; Gremyachinskiy, D. E.; Smith, L. L.; Bliznets, I. V.; Gross, P. H. Tetrahedron Lett. 2002, 43, 6329.

141.Gremyachinskiy, D. E.; Smith, L. L.; Gross, P. H.; Samoshin, V. V. Green Chem. 2002, 4, 317.

142.Ballini, R.; Marcantoni, E.; Petrini, M. Tetrahedron Lett. 1992, 33, 4835.

143. Fuerst, A.; Plattner, P. A. Helv. Chim. Acta 1949, 32, 275.

144.Motawia, M.; Wengel, J.; Abdel-Megid, A.; Pedersen, E. Synthesis 1989, 384.

145.Fischer, H. O. L. Ber. Dtch. Chem. Ges. 1921, 54, 775.

146. Trost, B.; Romero, A. J. Org. Chem. 1986, 51, 2332.

147.Lubineau, A.; Grand, E.; Scherrmann, M.-C. Carbohydr. Res. 1997, 297, 169.

148.Lubineau, A.; Arcostanzo, H.; Queneau, Y. J. Carbohydr. Chem. 1995, 14, 1307.

149.Lubineau, A.; Queneau, Y. J. Carbohydr. Chem. 1995, 14, 1295.

150.Lubineau, A.; Bienayme, H.; Queneau, Y. Carbohydr. Res. 1995, 270, 163.

151.Lubineau, A.; Auge, J.; Grand, E.; Lubin, N. Tetrahedron 1994, 50, 10265.

152.Lu, J.; Samoshin, V. V.; Gross, P. H. Glycobiology 2001, 11, 908.

153.Lu, J. The total synthesis of C-glycosides by cycloaddition reactions, Ph.D. Dissertation; University of the Pacific: Stockton, CA, USA, 2002.

154. Reichstein, T.; Weiss, E. Adv. Carbohydr. Chem. 1962, 17, 65.

155.Brazdova, B.; Samoshina, N. M.; Samoshin, V. V. In Abstracts of papers, 39th Western Regional Meeting of the ACS, Sacramento, CA, USA, 2004, pp GEN-071.

156. Brazdova, B.; Tan, N. S.; Samoshina, N. M.; Samoshin, V. V. In Abstracts of Papers, 232nd ACS National Meeting, San Francisco, CA, USA, 2006, pp BIOL-248.

157. Tan, N. S.; Brazdova, B.; Samoshina, N. M.; Samoshin, V. V. J. Undergrad. Chem. Res. 2007, 6, 186.

158. Brazdova, B.; Tan, N. S.; Samoshina, N. M.; Samoshin, V. V. Carbohydr. Res. 2009, in print. 


\section{Authors' biographies}

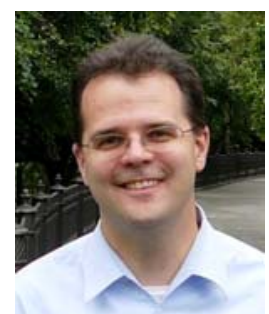

Dr. Andreas H. Franz is an associate professor in the Department of Chemistry at the University of the Pacific. He received a B.S. equivalent (Vordiplom) from the Universität Gesamthochschule Siegen (Germany) in 1994 and his Ph. D. from the University of the Pacific in 2000 for work in the synthesis and NMR structural characterization of oligosaccharide mimetics. After a post-doctoral research appointment at the University of California Davis where he studied methods of structure elucidation of natural oligosaccharides by Fourier Transform Ion-Cyclotron-Resonance mass spectrometry with Dr. Carlito B. Lebrilla, he returned to the University of the Pacific in 2002. He teaches organic chemistry, instrumental analysis, and advanced NMR spectroscopy. In 2007, he received funds from the National Science Foundation to establish and manage a $600 \mathrm{MHz}$ NMR facility at the University of the Pacific.

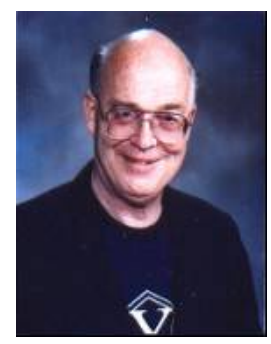

Dr. Paul H. Gross received his Ph. D. equivalent (Dr. Sci.) in 1961 from the Freie Universität Berlin, Germany. After a brief industrial appointment as a research chemist at Schering (peptide synthesis), he joined the faculty at the University of the Pacific in 1962. Following a research scientist appointment (1965-66) in the laboratory of Dr. Roger Jeanloz at Harvard Medical School where he focused on the synthesis of aminoglycosides, he returned to the University of the Pacific where he taught as full professor from 1970 until his retirement in 1998. Dr. Gross received numerous recognitions and grants including NSF and NIH funding for the development of new methods for the synthesis of aminosugars and aminomethyl-C-glycosides during his distinguished career. 


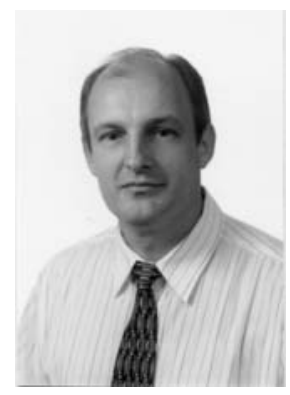

Vyacheslav V. Samoshin graduated with Honorable Diploma (M.S.) from Moscow State University, Russian Federation in 1974. At the same University, he defended his Ph.D. dissertation under the supervision of academician Nikolay S. Zefirov in 1982, and his Doctor of Chemical Sciences dissertation in 1991. He worked as a researcher in the Department of Chemistry, Moscow State University, and since 1992 as professor and head of the Division of Organic Chemistry in Moscow State Academy of Fine Chemical Technology. In 1999 he took his present position as professor of chemistry at the University of the Pacific, Stockton, California. His scientific interests include molecular switches, conformational analysis, carbohydrate mimetics, and crown ethers and relative compounds. 